\title{
ISOLAMENTO, SELEÇĀO E CARACTERIZAÇÃO DE MICRORGANISMOS PRODUTORES DE BIOSURFACTANTES
}

\section{ALESSANDRA PUPIN DO NASCIMENTO}

Licenciada em Ciências Biológicas

Orientador: Prof. Dr. FLAVIO CESAR ALMEIDA TAVARES

Dissertação apresentada à Escola

Superior de Agricultura "Luiz de Queiroz", Universidade de São Paulo, para obtenção do título de Mestre em Agronomia, Área de Concentração: Microbiologia Agrícola.

P I R A C I C A B A

Estado de São Paulo - Brasil

Março - 2003 
Dados Internacionais de Catalogação na Publicação (CIP) DIVISĀO DE BIBLIOTECA E DOCUMENTAÇĀO - ESALQ/USP

Nascimento, Alessandra Pupin do

Isolamento, seleção e caracterização de microrganismos produtores de biosurfactantes / Alessandra Pupin do Nascimento. - - Piracicaba, 2003.

$71 \mathrm{p}$.

Dissertação (mestrado) - - Escola Superior de Agricultura Luiz de Queiroz, 2003. Bibliografia.

1. Biotecnologia 2. Emulsificantes 3. População microbiana 4. Surfactantes 5. Tensoativos I. Titulo

CDD 664.06 
Ao meu marido, Vivaldo e a minha avó Ilda (in memorian)

\section{DEDICO}




\section{AGRADECIMENTOS}

À Deus, por iluminar sempre o meu caminho.

Ao Prof. Dr. Flavio Cesar Almeida Tavares, pela orientação e apoio.

Ao Dr. Luiz Humberto Gomes, à Dra. Keila Maria Roncato Duarte e à Técnica

Ana Maria Brancalion Giacomelli pelo carinho, paciência, amizade, colaboração com o meu trabalho e por toda ajuda no laboratório

Ao Prof. Dr. Marcelo Carnier Dornelas, pelo auxílio com as imagens de microscopia eletrônica de varredura.

Ao Prof. Dr. Luiz Gonzaga do Prado Filho, pelas idéias e pelo bom humor.

Ao Prof. Dr. Cláudio Rosa Gallo, pelo fornecimento dos meios de cultura.

Ao Prof. Dr. Fernando Campos Mendonça da UFU pela ajuda com a análise estatística.

Aos meus amigos do laboratório Jupará, Polé, Marcelo, Jonas, Carmo e Felipe.

À minha mãe, Eliana que lutou muito para que eu chegasse até aqui.

Ao meu marido, Vivaldo que sempre me incentivou e acreditou no meu potencial.

À CAPES, pela concessão da bolsa de Mestrado.

A todos que contribuíram de forma direta ou indireta para a realização deste trabalho. 


\section{SUMÁRIO}

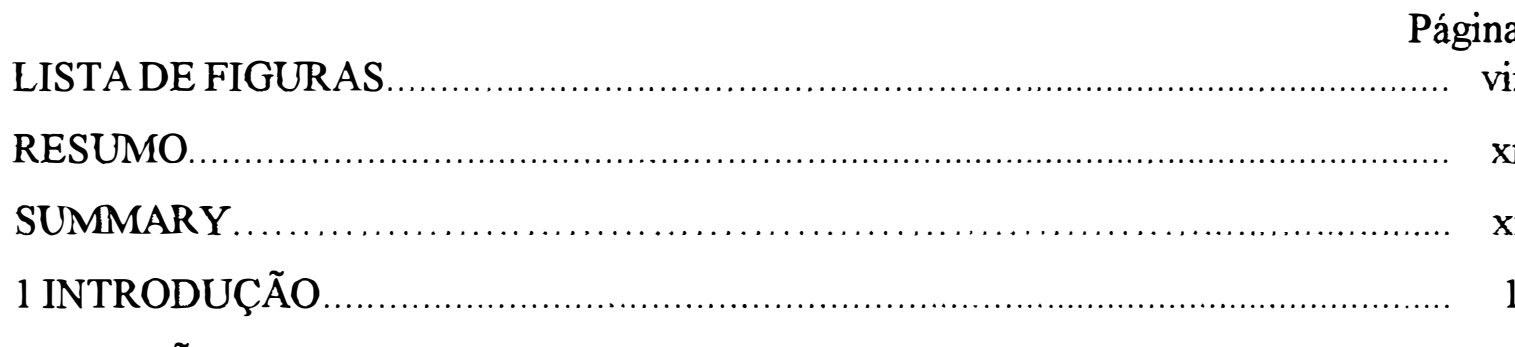

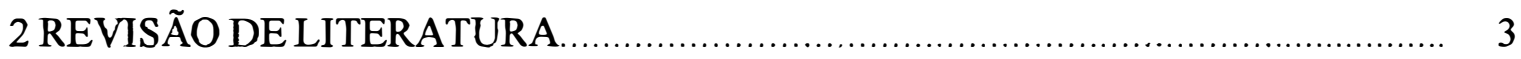

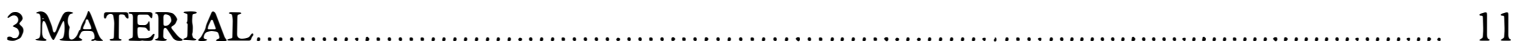

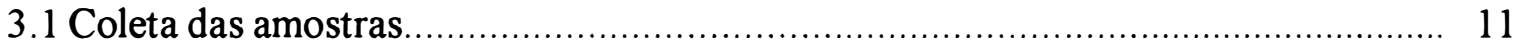

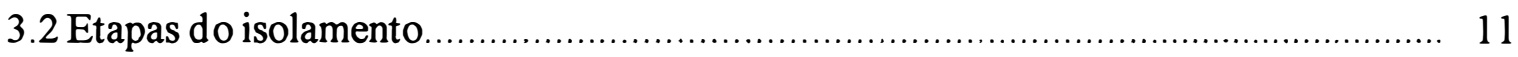

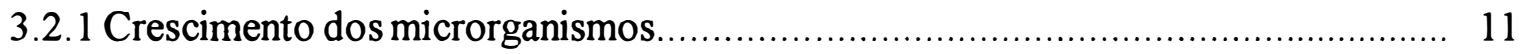

3.2.2. Multiplicação dos microrganismos para utilização nos testes ...................... 12

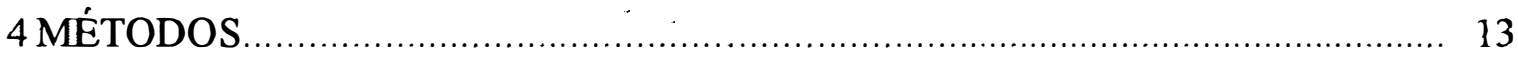

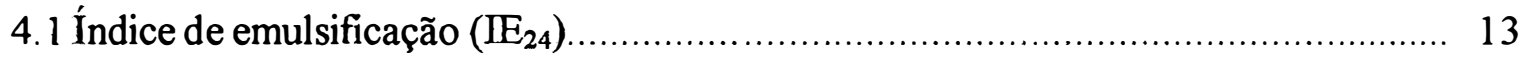

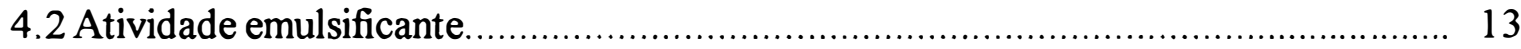

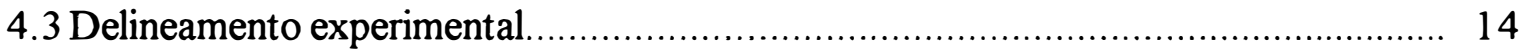

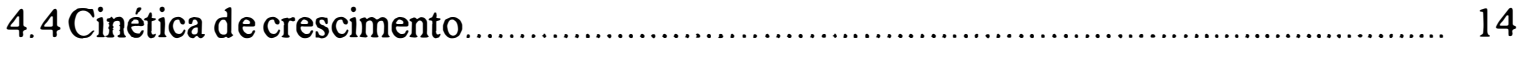

4.5 Coloração de Gram........................................................................... 15

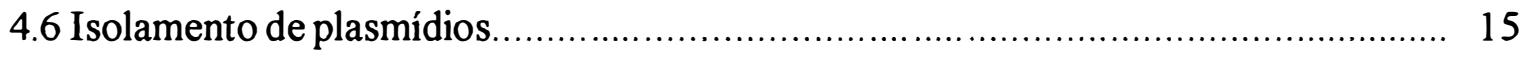

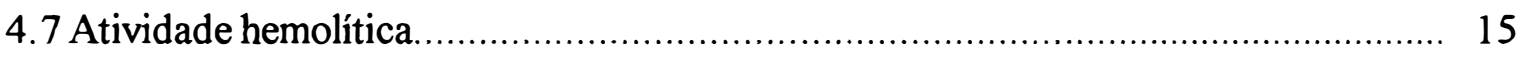

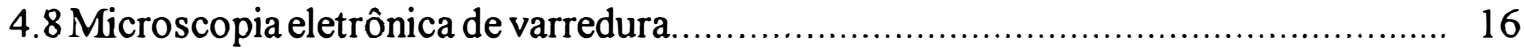

4.9 Identificação de bactérias através de provas bioquímicas.............................. 16

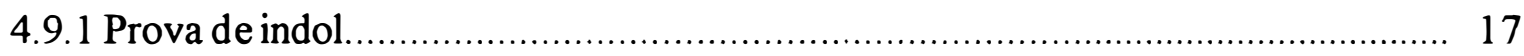

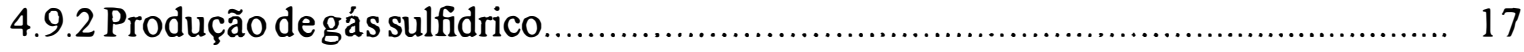


4.9.3 Prova do vermelho de metila (VM) 17

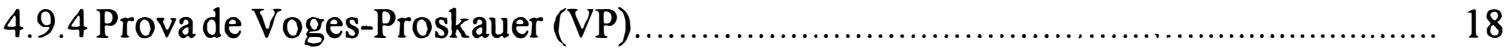

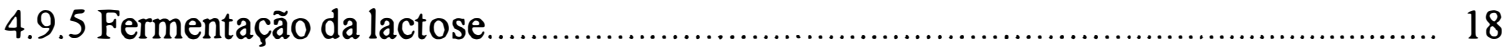

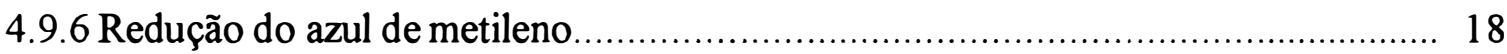

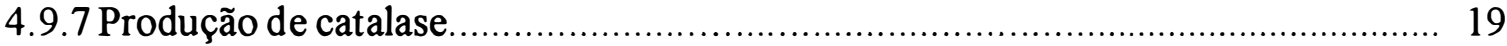

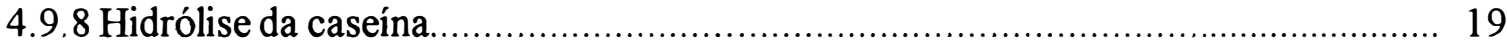

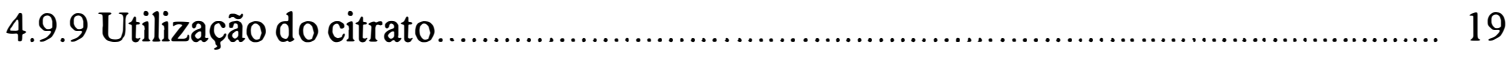

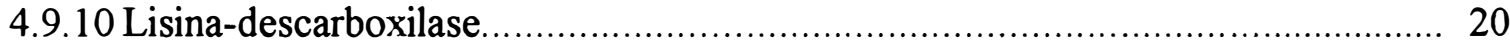

4.9.11 Pesquisa do movimento bacteriano.................................................... 20

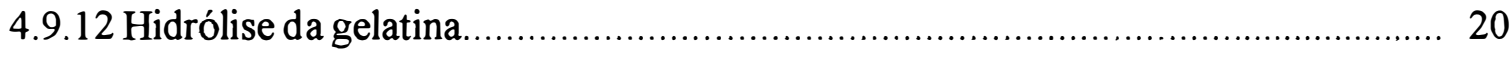

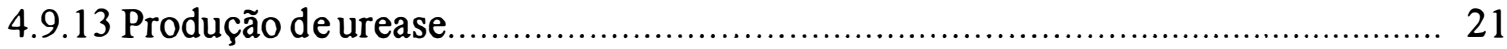

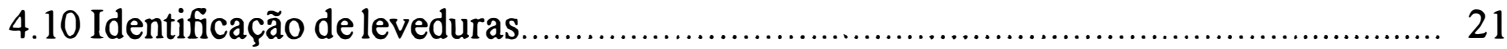

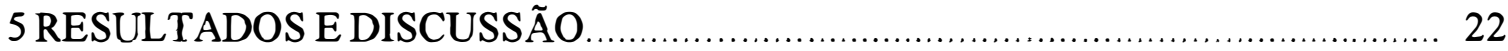

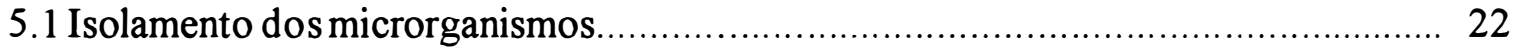

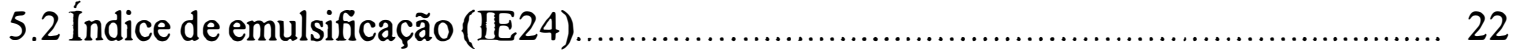

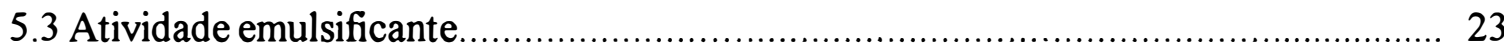

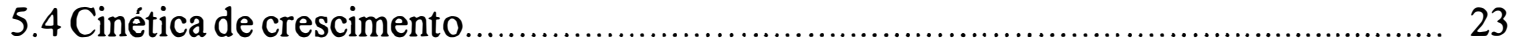

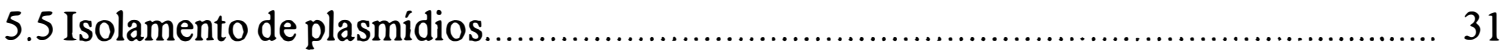

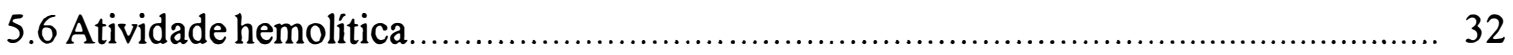

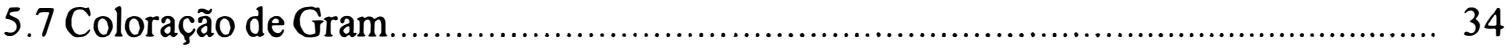

5.8 Provas bioquímica aplicadas á identificação de bactérias.............................. 34

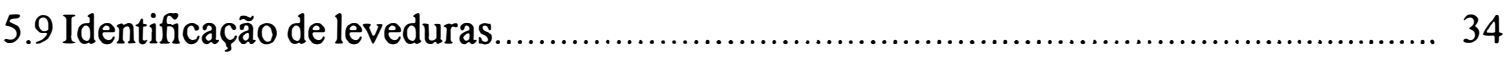

5.10 Microscopia eletrônica de varredura .................................................. 35

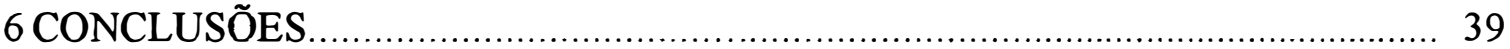

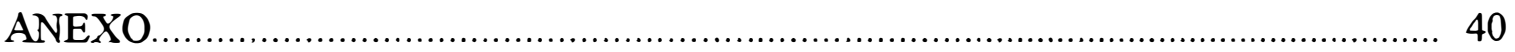

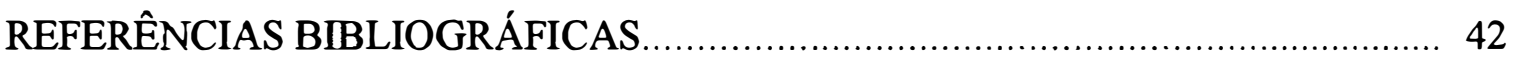

APÊNDICES 


\section{LISTA DE FIGURAS}

Página

1 Regressão linear para a fase exponencial da cinética de crescimento do isolado $\mathrm{B} 118$

2 Regressão linear para a fase exponencial da cinética de crescimento do isolado $\mathrm{B} 119$

3 Regressão linear para a fase exponencial da cinética de crescimento do isolado $\mathrm{B} 120$

4 Regressão linear para a fase exponencial da cinética de crescimento do isolado $\mathrm{B} 122$.

5 Regressão linear para a fase exponencial da cinética de crescimento do isolado B134......

6 Regressão linear para a fase exponencial da cinética de crescimento do isolado $\mathrm{B} 151$

7 Regressão linear para a fase exponencial da cinética de crescimento do isolado $\mathrm{B} 152$

8 Regressão linear para a fase exponencial da cinética de crescimento do isolado $\mathrm{B} 155$

9 Regressão linear para a fase exponencial da cinética de crescimento do isolado $\mathrm{B} 156$.

10 Regressão linear para a fase exponencial da cinética de crescimento do isolado $\mathrm{B} 157$

11 Regressão linear para a fase exponencial da cinética de crescimento do isolado $\mathrm{B} 174$ 
12 Regressão linear para a fase exponencial da cinética de crescimento de Acinetobacter calcoaceticus RAG1.

13 Regressão linear para a fase exponencial da cinética de crescimento de Bacillus licheniformis

14 Regressão linear para a fase exponencial da cinética de crescimento de Bacillus subtilis.

15 Atividade hemolítica. Crescimento de colônias após 24 horas de incubação em placas ágar-sangue. Colônia 1 - isolado B 118; Colônia 2 isolado B1 19; Colônia 3 - isoladoB120; Colônia 4 - isolado B122; Colônia 5 - isolado B134 e Colônia 6 - isolado B151.

16 Atividade hemolítica. Crescimento de colônias após 24 horas de incubação em placas ágar-sangue. Colônia 1 - isolado B152; Colônia 2 isolado B155; Colônia 3 - isoladoB156; Colônia 4 - isolado B157; Colônia 5 - isolado B174.

17 Atividade hemolítica. Crescimento de colônias após 24 horas de incubação em placas ágar-sangue. Colônia 1 - Acinetobacter calcoaceticus RAG1; Colônia 2 - Bacillus licheniformis; Colônia 3 Bacillus subtilis.

18 Fotomicrografia eletrônica de varredura dos isolados selecionados. $\mathrm{Na}$ figura A - isolado B119; figura B - isolado B134; figura C - isolado B151; figura D $\quad-\quad$ isolado B152. Aumento

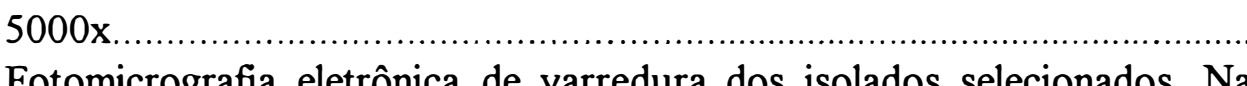

19 Fotomicrografia eletrônica de varredura dos isolados selecionados. $\mathrm{Na}$ figura A - isolado B155; figura B isolado B156; figura C - isolado B157. Aumento 5000x.

20 Fotomicrografia eletrônica de varredura dos isolados selecionados. $\mathrm{Na}$ figura A - Acinetobacter calcoaceticus RAG1; figura B - Bacillus licheniformis; figura C - Bacillus subtilis. Aumento $5000 x$ 


\title{
ISOLAMENTO, SELEÇÃO E CARACTERIZAÇÃO DE MICRORGANISMOS PRODUTORES DE BIOSURFACTANTES
}

\author{
Autor: ALESSANDRA PUPIN DO NASCIMENTO \\ Orientador: Prof. FLAVIO CESAR ALMEIDA TAVARES
}

\section{RESUMO}

Agentes tensoativos são compostos sintéticos, ou de origem biológica, com a propriedade de modificar a tensão superficial da água devido a sua natureza heteropolar. Dentre os agentes tensoativos microbianos incluem-se os surfactantes, que são compostos emulsificantes pouco caracterizados quimicamente. Os biosurfactantes geralmente possuem composição complexa, associando carboidratos, aminoácidos, fosfolipídeos, ácidos graxos e lipídeos neutros. Nas últimas décadas, os biosurfactantes estão ganhando proeminência superando os de origem química em várias aplicações industriais de importância, principalmente devido às vantagens de biodegradabilidade, produção a partir de matérias primas renováveis e funcionalidade sob condições extremas. Presentemente usam-se biosurfactantes principalmente no setor alimentício e petrolífero, onde são empregados na recuperação do óleo cru e na remediação de sítios poluídos. Dentro deste contexto, este trabalho teve por objetivo isolar e avaliar microrganismos com características emulsificantes. Foram isoladas leveduras e bactérias 
totalizando 280 microrganismos de diferentes microambientes, destes 9 bactérias e 2 leveduras após várias análises foram selecionadas. De acordo com os resultados obtidos verificou-se que a técnica foi eficiente no isolamento e avaliação dos microrganismos. No futuro esses microrganismos podem servir como fonte na produção de biosurfactantes, desde que conhecidas mais detalhadamente sua fisiologia e rotas de produção. 


\title{
ISOLATION, SELECTION AND CHARACTERIZATION OF BIOSURFACTANT PRODUCING MICRORGANISMS
}

\author{
Author: ALESSANDRA PUPIN DO NASCIMENTO \\ Adviser: Prof. FLAVIO CESAR ALMEIDA TAVARES
}

\section{SUMMARY}

Tensoactive agents are heteropolar compounds of synthetic or biological origin with the property of modifying the superficial tension of the water due to their heteropolar nature. Among the microbial tensoactives are included the surfactants that are emulsificants compounds not well characterized chemically. The biosurfactants usually have complex composition associating carbohydrates, amino acids, phospholipids, fatty acids and neutral lipids. In the last decades biosurfactants are getting overcoming those of chemical origin in several industrial important applications mainly due to the biodegradability advantages, production from renovable sources of raw material and functionality under extreme conditions. Biosurfactants are used mainly in the food industry and oil industries. One application is to recover crude petroleum in oil fiels, the remediation of polluted sites. Under this context this paper had the objective to isolate and evaluate microorganisms with emulsificant characteristics. Yeasts and bacteria were isolated in a total of 280 microorganisms of different environments from which 9 bacteria and 2 yeasts were selected. The results show efficiency in isolation and 
selection of the biosurfactant producing microorganisms. Such microorganisms are forever adequate for biosurfactants production and furhter studies are necessary regarding physiology and production routes in detail. 


\section{INTRODUÇÃO}

Surfactantes e emulsificantes são um grupo de moléculas coma atividade de superficie amplamente utilizados em diversos setores industriais. A maioria deles são compostos sintetizados quimicamente e somente nas últimas décadas é que moléculas com estas propriedades e de origem biológica têm sido descritas. As propriedades surfactantes e emulsificantes resultam da presença de ambas regiões hidrofilica e hidrofóbica na mesma molécula formam agregados moleculares em misturas água-óleo que se acumulam nos limites da superficie, separando as duas fases.

Os biosurfactantes possuem ampla aplicação. $\mathrm{Na}$ área agronômica são utilizados como agentes dispersantes para emulsificação de soluções de pesticidas. $\mathrm{Na}$ indústria de cosméticos e produtos de higiene pessoal são utilizados como emulsificantes e estabilizantes em bases, cremes, batons, removedores de maquiagem, shampoos e loções. Na indústria alimentícia são usados como emulsificantes e agentes espessantes em panificação, sorvetes e como solubilizantes de óleos flavorizantes. Na indústria petroquímica foram utilizados na recuperação do petróleo por microrganismos, na limpeza de tanques de estocagem, no transporte do petróleo bruto em oleodutos, no controle da poluição e como emulsificantes para lubrificantes.

A função fisiológica do biosurfactante é favorecer o crescimento de microrganismos em substratos insolúveis tornando-o disponível para sua utilização. Muitos microrganismos, a maioria bactérias e leveduras tem sido descritos como capazes de crescer em substratos insolúveis, graças à produção de biosurfactantes.

Dentre os microrganismos com propriedades surfactantes as espécies bactéria Acinetobacter calcoaceticus são mais conhecidas e Bacillus subtilis produtora do Emulsan e da surfactina, respctivamente. 
No momento, biosurfactantes são incapazes de competir economicamente no mercado com os compostos quimicamente sintetizados, devido a vários fatores com pequena escala de fermentações de baixa produtividade e o uso de substratos de custos elevados. Assim considera-se como pré-requisito para que os biosurfactantes ganhem espaço no mercado são a melhora das fermentações e melhorar o processo tecnológico para facilitar a recuperação de produtos.

Diante da possibilidade do uso de microrganismos com propriedades surfactantes no Brasil, o trabalho consiste de pesquisa exploratória quanto ao isolamento de espécies em vários locais supostamente favoráveis ao desenvolvimento de populações microbianas com atividade biosurfactante, avaliação de metodologias de análise e seleção. 


\section{REVISÃO DE LITERATURA}

Segundo Fiechter (1992), um surfactante é definido como uma molécula com atividade de superficie produzida por células vivas. A propriedade surfactante e emulsificante resulta da presença de regiões hidrofilica e hidrofóbica numa mesma molécula. O termo bioemulsificante é muitas vezes usado para descrever a combinação de todos os compostos com atividade de superficie secretados pela célula para facilitar a absorção de substratos insolúveis.

Banat (1995a) definiu biosurfactantes como um grupo heterogêneo de moléculas com atividade de superficie produzida por microrganismos. Estas moléculas reduzem a tensão superficial, a concentração micelar crítica (CMC) e a tensão interfacial em soluções aquosas e misturas de hidrocarbonetos. Estas propriedades criam microemulsões nas quais ocorrem a formação de micelas onde hidrocarbonetos podem solubilizar em água, ou água em hidrocarbonetos.

Microrganismos eucarióticos e procarióticos satisfazem suas necessidades de carbono e energia usando compostos como os hidrocarbonetos, que são pouco solúveis em meios aquosos. O crescimento se dá tanto em condições favoráveis de crecimento, quanto em condições extremas, como alta temperatura, pressão, salinidade e baixa tensão de oxigênio. $\mathrm{O}$ crescimento em hidrocarbonetos é freqüentemente associado com a produção de compostos com atividade de superficie (Koch et al., 1991).

Biosurfactantes incluem uma extensa variedade de estruturas químicas como os glicolipídeos, lipopeptídeos, polissacarídeos, fosfolipídeos, ácidos graxos e lipídeos neutros (Rosemberg, 1986).

Os diferentes biosurfactantes têm propriedades específicas de aplicação em função da natureza de sua estrutura lipofilica e hidrofilica (Cooper \& Zajic, 1980). Tem 
sido demonstrado que variações nos ácidos carboxílicos podem ter efeitos drásticos sobre as propriedades dos surfactantes, interferindo com a especificidade de atuação. Mudando o substrato freqüentemente altera-se a estrutura do produto, e a propriedade do surfactante. A escolha da fonte de carbono é, portanto determinante para a intenção específica de aplicação.

Segundo Banat (1995b) baseado no caráter da porção hidrofilica da molécula os biosurfactantes podem ser agrupados nas seguintes classes, a) glicolipídeos; b) fosfolipídeos c) lipídeos neutros d) ácidos graxos e e) lipopolissacarídeos.

Rosemberg (1986) dividiu os biosurfactantes em 3 categorias baseadas na natureza bioquímica do surfactante, se proteína, polissacarídeo, lipídeo ou um complexo contendo dois ou mais tipos destas biomoléculas. Sendo assim os biosurfactantes foram classificados em a) glicolipídeos que incluem os lipídeos de trealose, os soforolipídeos e os ramnolipídeos; b) ácidos graxos e c) fosfolipídeos.

O ramnolipídeo produzido por Pseudomonas aeruginosa tem a propriedade de baixar a tensão superficial e emulsificar hidrocarbonetos. Sua estrutura apresenta vários ácidos graxos hidroxil e carboidratos (Rosemberg, 1986).

Os lipopeptídeos extracelulares produzidos por alguns Bacillus sp. são biosurfactantes muito eficientes segundo Cooper et al. (1981) que isolou o lipopeptídeo surfactin a partir do meio de cultura livre de células cultivando Bacillus subtilis em glicose. Comercialmente o biosurfactante é denominado surfactina, sendo capaz de baixar a tensão superficial da água de $75 \mathrm{mN} \mathrm{m}^{-1}$ para $27 \mathrm{mN} \mathrm{m}^{-1}$. O coeficiente de tensão superficial é dado pela razão energia/área $\left(\mathrm{J} \mathrm{m}^{-2}\right)$, sendo também os valores do coeficiente de tensão superficial comumente apresentados em Newtons por metro $\left(\mathrm{N} \mathrm{m}^{-}\right.$ 1, porque $\left.1 \mathrm{~J}=1 \mathrm{~N} \mathrm{~m}^{-1}\right)($ Costa, 2001). Conforme Lang \& Wagner (1987), um bom biosurfactante é capaz de reduzir a tensão superficial para menos de $30 \mathrm{mN} \mathrm{m}^{-1}$.

A bactéria Acinetobacter calcoaceticus RAGl foi isolada e identificada por Gutnick \& Rosemberg (1977), sendo muito eficiente na emulsificação de hidrocarbonetos em água. A bactéria tem sido usada na limpeza de compartimentos de óleo. O fenômeno de "limpeza" é devido à produção de um fator extracelular e de alto peso molecular que foi denominado de Emulsan. 
A cinética de síntese e excreção de Emulsan no meio por $A$. calcoaceticus RAG1 crescido em meio mineral com etanol tem sido estudada extensivamente usando técnicas químicas, fisicas e imunológicas. Durante a fase exponencial, Emulsan, ou um precursor do Emulsan, se acumula na superficie da célula em minicápsulas (Pines et al., 1983; Rubnovitz et al., 1982). Durante a fase exponencial e início da fase estacionária, Emulsan é liberado no meio através de um processo dependente de energia. A rápida liberação do polímero Emulsan pré-formado pode ser causado pela falta de um aminoácido ou pela adição de inibidores de síntese protéica (Rubnovitz et al., 1982). Durante a inibição da síntese de proteínas, o lipopolissacarídeo continua sendo sintetizado.

A importância dos biosurfactantes está relacionada à ampla propriedade e a diversidade de estruturas em comparação aos surfactantes sintéticos. Pode-se destacar também que os biosurfactantes normalmente não são tóxicos (Banat et al., 1991; Muriel et al., 1996; Neu \& May, 1996) e são biodegradáveis, o que reduz o potencial de poluição (Cooper \& Zajic, 1980).

A aplicação dos biosurfactantes na recuperação intensificada do petróleo por microrganismos (MEOR) tem sido utilizada com sucesso. O processo consiste em tecnologia que utiliza microrganismos ou produtos de seu metabolismo para a recuperação de óleo residual (Banat, 1995). É estimado que somente 30-50\% do óleo pode ser extraído das reservas de petróleo pelas técnicas convencionais de bombeamento (Fiechter, 1992). Durante a extração do óleo cru a pressão no reservatório é diminuída, requerendo posterior injeção de água ou gás dentro do reservatório para a extração do óleo remanescente. $\mathrm{O}$ processo in situ deve-se a múltiplos efeitos dos microrganismos no ambiente e no óleo, que incluem a formação de gás e aumento da pressão, produção de ácidos e degradação da matriz calcárea, redução na viscosidade do óleo e da tensão interfacial pela produção de biosurfactantes, produção de solventes, degradação de macromoléculas do óleo e consequente diminuição da viscosidade (Jack, 1988). A utilização de biosurfactantes neste processo MEOR envolve várias estratégias, como a injeção de microrganismos produtores de biosurfactantes no reservatório e subseqüente produção in situ, ou a injeção de nutrientes no reservatório para estimular o crescimento 
de microrganismos produtores de biosurfactantes; ou ainda, a produção de biosurfactantes em reatores e posterior injeção no reservatório (Banat, 1995).

Para ser útil no processo MEOR in situ os microrganismos devem ser aptos a crescer em condições extremas, como alta temperatura, pressão, salinidade e baixa tensão de oxigênio (Karanth, 1999).

Surfactantes sintéticos têm sido usados na indústria de óleo para auxiliar na limpeza de derramamento de óleo e na recuperação do óleo dos reservatórios. Esses compostos não são biodegradáveis e podem ser tóxicos ao meio ambiente, enquanto que os biosurfactantes, tem mostrado em muitos casos com propriedades equivalentes de emulsificação, sendo biodegradáveis. Contudo, há um aumento no interesse de usar biosurfactantes na mobilização do óleo cru no transporte do petróleo em oleodutos, no controle de derramamentos de óleo, na limpeza de tanques de óleo e na recuperação intensificada do petróleo por microrganismos (Saker et al., 1989).

Os pré-requisitos para que os biosurfactantes sejam economicamente competitivos dependem de conhecimento sobre o metabolismo das cepas produtoras, do uso de substratos mais baratos e otimização dos processos de recuperação do produto (Fiechter, 1992).

\subsection{Importância fisiológica para os microrganismos}

Segundo Fiechter (1992), Ratledge (1988) e Muriel et al. (1996), o principal papel dos biosurfactantes é permitir aos microrganismos crescer em substratos imiscíveis em água pela redução da tensão superficial, tornando o substrato disponível para o seu metabolismo. A baixa solubilidade dos hidrocarbonetos em água impede seu uso direto pelos microrganismos, que necessitam de agentes emulsificantes para que se efetive a transferência de massa e aproveitamento desta fonte de carbono para a produção de energia componentes vitais. Existem microrganismos que sintetizam surfactantes crescendo em diferentes substratos, incluindo carboidratos a hidrocarbonetos (Cooper, 1986). Identificando-se duas vias possíveis de produção: a) extracelular, que causa emulsificação do hidrocarboneto fora da célula, e b) associado à 
parede celular, que facilita a entrada do hidrocarboneto no espaço periplasmático (Koch et al., 1991).

Normalmente a população de microrganismos degradadores de hidrocarbonetos do solo constitui menos de $1 \%$ da comunidade microbiana total, mas quando se acrescenta óleo, esta população pode aumentar para 10\% da comunidade (Atlas, 1995).

Entre os microrganismos presentes no solo são conhecidas mais de 100 espécies e aproximadamente 30 gêneros de fungos, bactérias e actinomicetos com potencial para metabolizar hidrocarbonetos, mas estudos têm demonstrado que estes números podem ser maiores (Rosato, 1997).

Segundo Cerniglia (1984), cianobactérias e algas também possuem a capacidade de oxidar hidrocarbonetos, porém, são restritos os estudos sobre estes grupos microbianos.

O nível de decomposição é marcadamente afetado pelo comprimento da cadeia e peso molecular dos hidrocarbonetos presentes no resíduo. Microrganismos específicos destroem moléculas como o fenol, o naftaleno e o antraceno (Blackburn \& Hafker, 1993). As bactérias são o grupo de microrganismos dominantes na degradação de compostos deste tipo, como Bacillus e Pseudomonas (Cerniglia, 1984), Mycobacterium, Acinetobacter e Arthrobacter (Alexander, 1977), Beijerinkia, Corynebacterium, Cianobacter, Flavobacterium, Micrococccus, Rhodococcus, Vibrio (Wilson \& Jones, 1993).

Entre os gêneros de actinomicetos envolvidos na degradação de hidrocarbonetos estão Streptomyces, Nocardia, Micromonospora e Actinomyces. Entre os fungos filamentosos os mais abundantes são Aspergillus, Penicillium, Cladosporium (atualmente conhecido como Hormoconis), Mortierelle, Trichoderma. Entre as leveduras tem-se Candida e Rhodotorula (Pipes, 1978).

De acordo com Rodrigues et al. (1996), em testes preliminares feitos com meio mineral descrito por Bushnell-Haas (1941) e óleo diesel como única fonte de carbono, Pediococcus sp e Bacillus sp. mostraram uma melhor capacidade de degradar o óleo; por outro lado, várias espécies de actinomicetos, Flavobacterium sp. e Pseudomonas aeruginosa não produziram quantidades consideráveis de $\mathrm{CO}_{2}$. 
A utilização de alcanos por diferentes microrganismos indica, segundo Finnerty \& Singer (1984), que há produção de diferentes tipos de moléculas de biosurfactantes intracelulares.

\subsection{Produção e aplicação dos biosurfactantes}

Microrganismos são capazes de produzir biosurfactantes podem em muitas situações substituir os surfactantes convencionais.

Emulsificantes são amplamente usados na indústria alimentícia, cosmética, agricultura, petrolífera e farmacêutica e podem ser substituídos conforme o caso pelos surfactantes de origem microbiana com a mesma eficiência. Na indústria alimentícia são amplamente usados como emulsificantes de sorvetes, pães e derivados de carnes (salsichas, patês, etc) e como solubilizantes de óleos flavorizantes. $\mathrm{Na}$ agricultura servem como dispersantes para soluções de pesticidas. Na indústria petrolífera ajudam na remoção de óleo de alta viscosidade dos poços. Podem ser usados na limpeza de tanques e no controle de derramamentos de óleo. $\mathrm{Na}$ indústria farmacêutica podem ser usados em loções oftálmicas e como emulsificantes de drogas (Jeneil Biosurfactant Company, 2002). Os materiais em uso comercial como surfactantes são produzidos principalmente por síntese química ou como subproduto de processos industriais, por exemplo, lignosulfonatos provenientes da indústria de papel (Rosemberg, 1986).

Muitos dos surfactantes sintetizados quimicamente resistem a biodegradação, se acumulam na natureza, e causam problemas ecológicos, ao passo que surfactantes microbianos como um produto natural, são suscetíveis a degradação por microrganismos na água e no solo (Shoham et al., 1983; Zajic et al., 1984).

Uma grande variedade de biosurfactantes produzidos por microrganismos tem sido descrita e seus tipos e quantidades são influenciadas por muitos fatores como a natureza da fonte de carbono, a concentração de $\mathrm{N}, \mathrm{P}, \mathrm{Mg}, \mathrm{Fe}$ e $\mathrm{Mn}$ no meio de cultura microbiano. As condições de cultura como $\mathrm{pH}$, temperatura, homogeneização e aeração também influenciam o tipo de biosurfactante produzido (Banat, 1995a). 
Biosurfactantes provenientes de microrganismos tem vantagens sobre os sintetizados quimicamente por causa de sua biodegradabilidade natural, e eficiência em uma ampla faixa de temperatura, $\mathrm{pH}$ e salinidade, e devido ao fato de poder ser sintetizado sob condições de baixas temperaturas e pressões (Shepherd et al., 1995).

Alguns dos biosurfactantes produzidos por microrganismos não são constitutivos e requerem a presença de alcanos para induzirem sua síntese. Wasko \& Bratt (1990) verificaram a produção de biosurfactantes em outras fontes que não hidrocarbonetos e sugeriram que o processo pode ser constitutivo e não induzido em função da produção de surfactante por Ochrobactrum antropii, um contaminante de óleo diesel, em meio com glicose e em meio mineral Bushnell-Haas sem a presença de hidrocarbonetos.

Os microrganismos, portanto, podem apresentar produção de biosurfactantes, seja crescendo tanto em substratos insolúveis como óleos, graxas e outros hidrocarbonetos (Ratledge, 1988), quanto em solúveis como carboidratos (Carrilo et al., 1996). Os mesmos compostos tensoativos que são normalmente excretados para utilização de n-alcanos por microrganismos produtores de biosurfactante, tais como $P$. aeruginosa e Torulopsis, são também excretados quando crescendo em fontes de carbono solúveis em água (Hommel, 1990). Para o processo industrial, os meios que usam carboidratos como fonte de carbono são os preferidos (Guerra-Santos et al., 1984).

A aplicação de biosurfactantes é realizada em bioremediação de solos contaminados, águas marinhas e costas litorâneas contaminadas (Bertrand et al., 1994), bem como em processos industriais, agrícolas e de alimentos. Métodos de purificação, ou extração, destes compostos vem sendo estudados por diversos autores (Jain et al., 1992; Pruthi \& Cameotra, 1995).

Embora os hidrocarbonetos possam sofrer fotólise, oxidação química e volatilização, a biodegradação é o principal processo de atuação sobre os compostos persistentes (Ashok et al., 1995; McGill et al., 1981).

As moléculas de hidrocarbonetos suscetíveis à oxidação microbiana podem ser de cadeias alifáticas e aromáticas (benzeno, tolueno, naftaleno, entre outros), longas, 
curtas, lineares ou ramificadas, que são modificadas para obtenção de compostos usados no metabolismo das células (Allsopp \& Seal, 1986).

Em geral, a bioxidação de óleos está acompanhada por emulsificação, resultando em uma interface água-óleo maior (Mercadé et al. 1996) e facilitando sua absorção pelas células. A alta atividade microbiana resulta então na remoção de moléculas complexas, no rompimento de anéis aromáticos, na redução de cadeias longas e, na transformação de cadeias insaturadas em saturadas (Morton et al., 1983). 


\section{MATERIAL}

\subsection{COLETA DAS AMOSTRAS}

As coletas das amostras de óleo, gorduras, graxas e hidrocarbonetos foram realizadas em ambientes, como açougues (mesa de corte, ralo da pia, ralo do chão, trilho do elevador), laticínios (pias, ralo do chão, embaladeira, tanque de resfriamento), postos de gasolina (ralo da troca de óleo e canaleta de escoamento) e Estações de Tratamento de Esgoto (caixa de gordura e gordura periférica da lagoa). Foram também coletadas amostras de solos impregnado com óleo proveniente do motor. As amostras de gorduras, graxas, óleos e hidrocarbonetos foram coletadas com palitos esterilizados e colocadas em frascos esterilizados. Retirou-se $900 \mathrm{~g}$ de cada amostra e homogeneizou-se com $1 \mathrm{~mL}$ de água Milli-Q esterilizada.

\section{2 ETAPAS DO ISOLAMENTO}

\subsubsection{Crescimento e isolamento dos microrganismos}

Após a suspensão de $900 \mathrm{mg}$ das amostras gorduras, graxas, óleos e hidrocarbonetos em $1 \mathrm{~mL}$ de água Milli-Q, $500 \mu \mathrm{L}$ desta suspensão proveniente dos diversos locais de coleta foi colocado em frascos de Erlenmeyers de $125 \mathrm{~mL}$ contendo $30 \mathrm{~mL}$ do meio mineral (Rosemberg, 1979) e $2 \%$ de etanol e incubados sob agitação de $100 \mathrm{rpm}$ a $34^{\circ} \mathrm{C}$ por 48 horas. Um frasco de Erlenmeyer sob as mesmas condições foi mantido sem inoculação, como controle. 
As culturas foram suplementadas por 2 vezes a cada 48 horas adicionando-se $5 \%$ de meio mineral $10 x$ concentrado e $2 \%$ de etanol. Após esse período foi feita novamente a suplementação com 5\% de meio mineral 10x concentrado, sendo que desta vez foi adicionado $2 \%$ de querosene (marca comercial Búfalo), incubado-se por mais 48

horas, totalizando 144 horas de incubação. Após essa etapa procedeu-se o isolamento em placas, onde $100 \mu \mathrm{L}$ da suspensão do meio de cultura foi colocado sobre o meio mineral sólido com glicose (Apêndice 1.2) e pela técnica da semeadura em superfície o inóculo foi espalhado na superfície do ágar com o auxílio de uma alça de vidro (alça de Digralsky)

Após 48 horas de incubação a $34^{\circ} \mathrm{C}$ em estufa incubadora as colônias foram isoladas e separadas, e novamente inoculadas em meio mineral sólido com glicose pela técnica de esgotamento por estrias que consiste em esgotar o material por meio de estrias na superficie do meio com uma alça ou agulha de semeadura para obter colônias isoladas e, portanto separá-las.

Todos as colônias obtidas foram crescidas em $3 \mathrm{~mL}$ de meio YEPD por 48 horas a $34^{\circ} \mathrm{C}$. Após o crescimento, $500 \mu \mathrm{L}$ da suspensão de microrganismos foi adicionada à $500 \mu \mathrm{L}$ de glicerol $70 \%$ em tubos do tipo "Eppendorf" de $1,5 \mathrm{~mL}$ e mantidas a $-80^{\circ} \mathrm{C}$ para utilização nos testes seguintes.

\subsubsection{Multiplicação dos microrganismos para utilização nos testes}

Os microrganismos isolados foram crescidos em $30 \mathrm{~mL}$ de meio mineral (Apêndice 1.1) e $2 \%$ de etanol e incubados sob agitação de $100 \mathrm{rpm}$ a $34^{\circ} \mathrm{C}$ por 48 horas. Foi feita a suplementação por 2 vezes a cada 48 horas adicionando-se à cultura $5 \%$ de meio mineral $10 x$ concentrado e $2 \%$ de etanol. Após esse período foi feita novamente a suplementação com $5 \%$ de meio mineral $10 x$ concentrado, sendo que desta vez foi adicionado $2 \%$ de querosene (marca comercial Búfalo), incubado-se por mais 48 horas, totalizando 144 horas incubação. 


\section{MÉTODOS}

\section{1 Índice de Emulsificação $\left(\mathrm{IE}_{24}\right)$}

$O$ índice de emulsificação $\left(\mathrm{IE}_{24}\right)$ é um teste simples que consiste em verificar visualmente a produção de biosurfactante pela formação de uma emulsão estável entre o meio de cultura livre de células e o querosene. $\mathrm{O}$ índice de emulsificação consiste em colocar uma alíquota de $2 \mathrm{~mL}$ da cultura centrifugada a $12000 \mathrm{~g}$, em tubo de ensaio com fundo chato adicionando o mesmo volume de querosene (marca comercial Búfalo) e $200 \mu \mathrm{L}$ de corante rosa bengala $0,1 \%$ para facilitar a visualização das fases e agitar em vortex por 1 minuto em alta rotação (Cooper \& Goldenberg, 1987). Após 24 horas calculou-se a razão entre a altura da região emulsificada e a altura total, e multiplicou-se por 100 para obtenção da porcentagem de emulsificação. Os isolados de bactérias e leveduras foram testados quanto ao $\mathrm{IE}_{24} \mathrm{e} o$ teste foi conduzido em triplicata.

\subsection{Atividade emulsificante}

A atividade emulsificante é a análise quantitativa utilizada para verificar a produção de biosurfactante e foi desenvolvido com base na estabilidade da emulsão formada pelo metilnaftaleno em tampão Tris (Shoham et al., 1983).

A atividade emulsificante foi determinada por um ensaio de emulsificação (Rosemberg et al., 1979) a qual é baseada na mistura de $100 \mu \mathrm{L}$ da solução de hexadecano e 2-metilnaftaleno (1:1) em 7,5mL de tampão Tris-Magnésio (20mM Tris e $10 \mathrm{mM} \mathrm{MgSO}_{4}[\mathrm{pH} 7.0]$ ) e $500 \mu \mathrm{L}$ da amostra centrifugada a $12000 \mathrm{~g}$. A mistura foi homogeneizada em mesa agitadora por 1 hora a $30^{\circ} \mathrm{C}$, a turbidez foi medida no 
colorímetro Klett-Summerson com filtro verde. O cálculo da atividade emulsificante (U $\mathrm{mL}^{-1}$ ) é dado pela Equação 1 .

Fator de diluição $=7,5 /$ volume da amostra

$\mathrm{U} \mathrm{mL}^{-1}=\underline{\text { unidades Klett } \mathrm{x} \text { fator de diluição. }} \quad$ Equação (1)

100

O teste da atividade emulsificante foi conduzido em triplicata.

\subsection{Delineamento experimental}

O delineamento experimental utilizado foi o inteiramente casualizado, sendo que para cada um dos 263 isolados foram feitas 3 repetições da análise do índice de emulsificação $\left(\mathbb{I E}_{24}\right)$ e 3 repetições da análise da atividade emulsificante. Para comparação de médias foi utilizado o teste de Tukey ao nível de $5 \%$. O programa utilizado para fazer a análise estatística foi o StatiGraphics. A análise estatística foi feita para a seleção dos melhores isolados quanto ao índice de emulsificação e atividade emulsificante.

\subsection{Cinética de crescimento}

O pré-inóculo utilizado para fazer a cinética de crescimento foi preparado suplementando-se o meio de cultura mineral com meio mineral 10x concentrado a cada 6 horas durante 24 horas. Os isolados selecionados estatisticamente (B118, B119, B120, B122, B134, B151 B152, B155, B156, B157 e B174) e os 3 padrões (Acinetobacter calcoaceticus RAG1, Bacillus licheniformis, Bacillus subtilis) foram crescidos em frascos de Erlenmeyer de $250 \mathrm{~mL}$ contendo $100 \mathrm{~mL}$ de meio mineral e mantidos a $34^{\circ} \mathrm{C}$ sob agitação constante. A cada 2 horas foi retirada uma alíquota de $1 \mathrm{~mL}$ para a leitura em espectrofotômetro Beckman DU640 a 580nm.

Também foi determinado o coeficiente de determinação que tem por objetivo avaliar a qualidade do ajuste da reta aos pontos observados. Normalmente um ajustamento entre 65 e $75 \%$ pode ser considerado regular; entre 75 e $85 \%$ pode ser 
considerado bom e acima de $85 \%$ deve ser considerado ótimo (Vanni, 1998). Dada a equação $\mathbf{y}=\mathbf{a}+\mathbf{b x}$ para a cinética de crescimento temos que y é a absorbância, a é o coeficiente linear da reta, $\mathbf{x}$ é o tempo dado em horas e $\mathbf{b}$ é o coeficiente angular da reta.

\subsection{Coloração de Gram}

A técnica da coloração de Gram consistiu em colocar 1 ou 2 gotas da suspensão de células em uma lâmina de vidro e espalhar procurando obter um esfregaço fino. O esfregaço na chama foi fixado na chama do bico de Bunsen, passando a lâmina algumas vezes pela chama sem deixar aquecer por muito tempo e até que fique bem seca. A lâmina foi coberta algumas gotas da solução de cristal violeta $(0,5 \%)$ e deixada por 20 segundos. A lâmina foi lavada com a solução de iodo $(2 \%)$ e que foi reaplicada deixando por 1 minuto. A lâmina foi lavada com álcool etílico deixando por alguns segundos somente. Lavar a lâmina com água destilada. A lâmina foi contracorada com a solução de safranina (1\%) por 1 minuto. A metodologia da coloração de Gram foi feita de acordo com Collins \& Lyne (1976).

\subsection{Isolamento de plasmídios}

As bactérias foram cultivadas em $30 \mathrm{~mL}$ de meio mineral com $2 \%$ de etanol. Após o crescimento, os plasmídios foram isolados utilizando-se o "Concert High Purity Plasmid Miniprep System" (Gibco-BRL-1 1453-016) de acordo com as recomendações do fabricante e a presença dos plasmídios visualizados em gel de agarose $0,8 \%$.

\subsection{Atividade hemolítica}

A atividade hemolítica é um teste usado por alguns autores (Jain et al., 1992; Banat, 1993) para a observação da produção de substâncias emulsificantes. A leitura indica que a formação de halos de hemólise ao redor das colônias pode estar correlacionada com a produção de biosurfactantes pelos microrganismos. 
A inoculação em ágar sangue foi realizada com um marcador circular esterilizado a fim de se observar a formação de halos de hemólise. Os marcadores circulares foram feitos utilizando-se lápis dividos em 3 partes iguais e de modo que ficassem com as pontas achatadas. Cada parte foi embrulhada individualmente em papel alumínio e esterilizada em autoclave. Foi utilizado como fonte de inóculo culturas com 48 horas dos isolados crescidos em placas de meio YEPD. O marcador circular esterilizado foi colocado em contato com as culturas e em seguida aplicado no ágar sangue. As placas foram incubadas a $30^{\circ} \mathrm{C}$ por 24 horas.

\subsection{Microscopia Eletrônica de Varredura}

Alguns dos isolados selecionados (B119, B134, B151 B152, B155, B156, B157) e os microrganimos utilizados como padrões foram fixados e preparados, objetivando o exame da superficie das células sob microscopia eletrônica de varredura (MEV). Os microrganismos foram crescidos em meio mineral com $2 \%$ de etanol por 48 horas sob agitação constante. Depois foram centrifugadas e o sobrenadante descartado. A fixação do material a ser submetido à MEV foi desidratado em série etílica consistiu em lavar as células com álcool etílico na concentração de $20 \%, 30 \%, 40 \%, 50 \%, 60 \%$, $70 \%, 80 \%, 90 \%$ sendo que a última lavagem foi feita com álcool etílico absoluto P.A. (99,5\%). A conservação das células também foi feita em álcool etílico absoluto P.A. (99,5\%). Após a desidratação, o material foi metalizado com ouro coloidal (camada de 40nm). A observação foi feita no microscópio de varredura (LEO 435 VP) do NAP/MEPA-ESALQ/USP. As imagens digitalizadas das observações foram obtidas utilizando-se o programa LEOUIF da Microsoft (Kitajima \& Leite, 1999).

\subsection{Identificação de bactérias através de provas bioquímicas}

Os testes bioquímicos são uma das bases para a identificação e são utilizados como método na sistemática bacteriana. As bactérias são classificadas utilizando-se Foram feitos os testes bioquímicos para produção de indol, produção de gás sulfidrico, 
VM, VP, fermentação da lactose, redução do azul de metileno, produção de catalase, hidrólise da caseína, utilização do citrato, lisina-descarboxilase, teste de motilidade, produção de gelatinase, produção de urease. A metodologia utilizada na identificação dos 9 isolados selecionados (B118, B119, B120, B122, B134, B151 B152, B155 e B174) foi feita de acordo com Silva et al. (1997).

\subsubsection{Teste da produção de indol}

O teste é utilizado para determinar a habilidade da bactéria em produzir indol através da desaminação do triptofano na presença da enzima triptofanase.

A cultura bacteriana foi inoculada em tubo com caldo indol e incubada por 4 dias a $35^{\circ} \mathrm{C}$ em estufa. Após a incubação, adicionou-se $2 \mathrm{~mL}$ de reativo de Kovacs e agitou-se. Com o repouso 2 camadas se separaram. A reação será positiva se houver coloração vermelha na superficie e será negativa se houver coloração amarela na superficie (Silva et al., 1997), indicando habilidade da bactéria em produzir indol através da desaminação do triptofano na presença da enzima triptofanase.

\subsubsection{Teste da produção de gás sulfídrico}

Este teste verifica se a bactéria é capaz de utilizar a cisteína ou a peptona como fonte de nitrogênio.

A cultura bacteriana foi inoculada em placas de Petri contendo meio bismuto sulfito ágar e incubar por 3 dias a $35^{\circ} \mathrm{C}$ em estufa. $\mathrm{O}$ resultado será positivo se colônias forem negras o que é indicativo da presença de $\mathrm{H}_{2} \mathrm{~S}$ e o resultado será negativo se as colônias forem amarelas devido a ausência de $\mathrm{H}_{2} \mathrm{~S}$ (Silva et al., 1997).

\subsubsection{Teste do vermelho de metila (VM)}

Este teste está baseado na capacidade de certos microrganismos produzirem a partir da glicose ácido suficiente para levar o $\mathrm{pH}$ abaixo de 4,2. 
A cultura foi inoculada em caldo de Clark e Lubs e após 3 dias de incubação a $35^{\circ} \mathrm{C}$ em estufa, adicionou-se ao tubo 3 a 5 gotas do indicador vermelho de metila. A coloração vermelha indica prova positiva e a coloração amarela indica prova negativa (Silva et al., 1997).

\subsubsection{Teste de Voges-Proskauer (VP)}

Este teste determina a capacidade de alguns microrganismos produzirem acetoína (produto final neutro) a partir da fermentação da glicose.

Inoculou-se a cultura em caldo de Clark e Lubs e após 3 dias de incubação a $35^{\circ} \mathrm{C}$ em estufa, adicionou-se ao tubo $0,5 \mathrm{~mL}$ da solução de $\alpha$ naftol e $0,5 \mathrm{~mL}$ de reativo de Barrit)/mL de suspensão bacteriana. A coloração vermelha na superficie indica reação positiva e a coloração amarela indica reação negativa (Silva et al., 1997).

\subsubsection{Teste da fermentação da lactose}

Este meio indica a habilidade de um microrganismo fermentar a lactose.

Após 4 dias de incubação da cultura em caldo lactosado a $35^{\circ} \mathrm{C}$ em estufa, verificou-se a produção de ácido e gás. A verificação da acidez se faz pela adição do indicador púrpura de bromocresol. A produção de gás pode ser verificada pela presença de bolhas no tubo de Duhram (Silva et al., 1997).

\subsubsection{Teste da redução do azul de metileno}

A medida da atividade da desidrogenase succínica pode ser feita utilizando-se um aceptor artificial de elétrons como oxidante final, desde que possua um potencial redox desviando toda a sequiência natural de transporte de elétrons dos citocromos. $\mathrm{O}$ azul de metileno é um possível aceptor final de elétrons que é azul em solução aquosa em atmosfera aerada e que na presença de um redutor e de uma atmosfera livre de oxigênio é reduzido tornando-se incolor. 
Inoculou-se a cultura em caldo simples e após a incubação de 48 horas a $35^{\circ} \mathrm{C}$ em estufa, adicionou-se $1 \mathrm{~mL}$ de solução de azul de metileno $(0,2 \%)$. Incubar a $37^{\circ} \mathrm{C}$ e examinar com intervalos de 15 minutos, até que o meio esteja completamente descorado (Silva et al., 1997).

\subsubsection{Teste da produção de catalase}

O teste é utilizado para detectar a presença da enzima catalase no sistema bacteriano através do peróxido de hidrogênio $\left(\mathrm{H}_{2} \mathrm{O}_{2}\right)$.

A cultura bacteriana foi inoculada em caldo nutriente e após incubação de 48 horas a $35^{\circ} \mathrm{C}$ em estufa, adicionou-se algumas gotas de peróxido de hidrogênio. Se houver desprendimento de bolhas a reação será positiva (Silva et al., 1997).

\subsubsection{Teste de hidrólise da caseína}

$\mathrm{O}$ teste mostra se o microrganismo tem habilidade proteolítica. A hidrólise da caseína é devido à ação proteolítica de algumas enzimas e resulta na clarificação do meio.

Inoculou-se a cultura bacteriana em ágar leite por 48 horas a $35^{\circ} \mathrm{C}$ em estufa e após a incubação observou-se o aspecto da colônia. A reação será positiva se houver zonas claras ao redor das colônias (Silva et al., 1997).

\subsubsection{Teste da utilização do citrato}

Este teste serve para identificar os microrganismos que utilizam o citrato como única fonte de carbono.

A cultura bacteriana foi inoculada em meio de citrato-Simmons e incubar por 48 horas a $35^{\circ} \mathrm{C}$ em estufa, observando-se o crescimento da cultura. A reação será positiva se houver crescimento e o meio adquirir cor azul (Silva et al., 1997). 


\subsubsection{Teste da lisina-descarboxilase}

A liberação de $\mathrm{HCO}_{3}{ }^{-}$do aminoácido lisina provoca uma alcalinização no meio de cultura transformando a cor amarela do indicador de $\mathrm{pH}$ púrpura bromocresol em coloração roxa.

A cultura bacteriana foi inoculada em meio lisina-descarboxilase e incubada por 48 horas a $35^{\circ} \mathrm{C}$ em estufa. Após a incubação adicionou-se $1 \mathrm{~mL}$ de óleo mineral (marca comercial Nujol) para evitar a penetração de oxigênio, pois esta reação só ocorre em anaerobiose. A reação será positiva se o meio ficar lilás (alcalino) e a reação será negativa se meio ficar amarelo (ácido) (Silva et al., 1997).

\subsubsection{Teste de motilidade}

Este teste permite verificar se o microrganismo possui flagelos que são as estruturas responsáveis pela motilidade da célula no meio de cultura.

Inoculou-se a cultura em meio Nutriente Ágar semi-sólido em "picada" e incubar por 48 horas a $35^{\circ} \mathrm{C}$. A reação será positiva se a bactéria crescer além da linha de picada e negativa se o meio permanecer límpido ou se houver crescimento só no local do inóculo (Silva et al., 1997).

\subsubsection{Teste da produção de gelatinase}

Este teste serve para identificar microrganismos produtores da gelatinase que é a enzima que liquefaz a gelatina.

Inoculou-se a cultura em meio de gelatina e após incubação de 48 horas a $35^{\circ} \mathrm{C}$, observar a ocorrência ou não da hidrólise da gelatina. Colocar os tubos em geladeira e verificar se houve solidificação. Se o meio solidificar é porque não houve hidrólise. Se a hidrólise tiver ocorrido a gelatina não volta a se solidificar. Classificar a hidrólise como: nenhuma, escassa, moderada ou completa (Silva et al., 1997). 


\subsubsection{Teste da produção de urease}

O teste indica se a bactéria, ao hidrolisar a uréia para amônia, em reação alcalina, produz a enzima urease.

Inoculou-se a cultura em meio Urea Agar Base e incubou-se por 48 horas a $35^{\circ} \mathrm{C}$ em estufa. $\mathrm{O}$ resultado positivo (rosa escuro) indica que a bactéria possui a enzima urease, que hidrolisa a uréia em amônia, alcalinizando o meio. $\mathrm{O}$ indicador amarelo ( $\mathrm{pH}$ $6,8)$ passa para rosa-escuro ( $\mathrm{pH} 8,0$ ) (Silva et al., 1997).

\subsection{Identificação de leveduras}

Como todos os microrganismos isolados foram previamente crescidos em placas de Petri, foram feitas lâminas para visualização ao microscópio, determinando-se então que os isolados B156 e B157 eram leveduras.

As propriedades fisiológicas servem para diferenciar e identificar espécies de leveduras. O teste para a identificação de leveduras consistiu na habilidade de cada levedura crescer aerobiamente em cerca de 18 compostos, cada um com uma fonte de carbono diferente. Testes de crescimento aeróbio são chamados "testes de assimilação" (Kreger-van Rij, 1984).

Os isolados B156 e B157 foram crescidos tubos de ensaio contendo meio YEPD (Apêndice 1.4) onde a fonte de carbono foi variada. Como fonte de carbono foi utilizada glicose, galactose, sacarose, celobiose, trealose, lactose, melibiose, rafinose, melezitose, amido, arabinose, etanol, glicerol, manitol, inositol, arbutin. Também foi feito o crescimento a $37^{\circ} \mathrm{C}$. A metodologia utilizada para a identificação dos isolados B 156 e B 157 foi feita de acordo com Barnett \& Pankhurst (1974). 


\section{RESULTADOS E DISCUSSÃO}

\subsection{Isolamento dos microrganismos}

Inicialmente foram isolados 280 microrganismos entre leveduras e bactérias provenientes de diferentes ambientes contaminados com óleos, gorduras, graxas e hidrocarbonetos. As coletas foram realizadas na cidade de Piracicaba. Dos 280 microrganismos isolados 161 apresentaram formação de emulsão pelo teste do índice de emulsificação, enquanto os outros 119 isolados que não apresentaram formação de emulsão pelo teste do Índice de Emulsificação foram descartados. Depois foram selecionados 11 microrganismos que obtiveram valores superiores quanto ao índice de emulsificação $\left(\mathrm{IE}_{24}\right)$ e atividade emulsificante quando comparados com os microrganismos utilizados como padrões. Os dados foram anlisados estatisticamente e pelo teste de Tukey com 5\% de significância no programa StatiGraphics, foram selecionados os que apresentaram melhores índices no $\mathrm{IE}_{24}$ e na atividade emulsificante, foram realizadas análises para a caracterização dos microrganismos e avaliação da produção de biosurfactante.

Para o crescimento dos microrganismos foi adicionado ao meio de cultura etanol como fonte de carbono. O etanol foi utilizado como fonte de carbono por se tratar de um substrato oxidável.

\section{2 Índice de Emulsificação $\left(\mathrm{IE}_{24}\right)$}

Foram selecionados 11 microrganismos com maior $\mathrm{IE}_{24}$ que mostraram ter resultados significantes na análise do índice de emulsificação quando comparado aos 
valores encontrados para os índices dos demais isolados e aos microrganismos utilizados como padrões (Anexo 1).

\subsection{Atividade emulsificante}

O teste da atividade emulsificante se baseia na análise da produção de substâncias com propriedades emulsificantes do tipo emulsan de natureza lipopolissacarídica. Foram selecionados 11 microrganismos com maior atividade emulsificante que mostraram ter resultados significantes na análise do índice de emulsificação quando comparado aos valores encontrados para os índices dos demais isolados e aos microrganismos utilizados como padrões (Anexo 1). Os microrganismos B118, B119, B120, B122, B134, B151, B152, B155, B156, B157 e B174 mostraram ser significantes estatisticamente quando comparado aos demais isolados $\mathrm{e}$ aos microrganismos utilizados como padrões.

Foi feita análise de regressão e como pôde ser verificado não existiu uma correlação entre os isolados que obtiveram valores significativos do índice de emulsificação $\left(\mathrm{IE}_{24}\right)$ e atividade emulsificante, ou seja, os resultados das duas análises não produziram valores similares. Somente o microrganismo B119 obteve correlação entre os valores de $\mathrm{IE}_{24}$ e atividade emulsificante. $\mathrm{O}$ que provavelmente pode estar ocorrendo é que no $\mathbb{E}_{24}$ outros tipos de substâncias podem estar causando a emulsificação que não são do tipo emulsan de natureza lipopolissacarídica e, como a análise da atividade emulsificante é específica para a produção da substância emulsan (lipopolissacarídica) esses valores não possuem relação, nem valores similares.

\subsection{Cinética de crescimento}

As velocidades de crescimento foram estimadas utilizando-se análise de regressão linear, que é um método que procura estabelecer relações funcionais entre duas ou mais variáveis, isto é, procura encontrar um modelo que descreva da melhor e mais segura forma possível, o comportamento das variáveis que estamos interessados 
em analisar. A equação da reta ajustada é representada por $\mathbf{y}=\mathbf{a}+\mathbf{b x}$, onde a representa o coeficiente linear da reta e $\mathbf{b}$ representa a declividade da reta. $\mathrm{O}$ fato de um coeficiente angular ser maior que outro indica que a reta associada a este coeficiente cresce mais rapidamente que a outra reta.

Observando-se o Anexo 1 vemos que $B$. subtilis obteve maior valor de $m$ tendo maior crescimento celular em menos tempo. Os microrganismos B152 e $B$. licheniformis foram os que obtiveram menor valor de a indicando assim que foram os mais lentos no crescimento.

Acinetobacter calcoaceticus RAGl foi o microrganismo que manteve a curva de crescimento mais uniforme e com maior valor de a.

Foram utilizados como padrões os microrganismos $A$. calcoaceticus RAG1, $B$. licheniformis e B. subtilis que são microrganismos produtores de biosurfactantes já caracterizados.

Os gráficos das análises de regressão, suas respectivas equações e coeficientes de determinação são mostrados nas Figuras de 1 a 14.

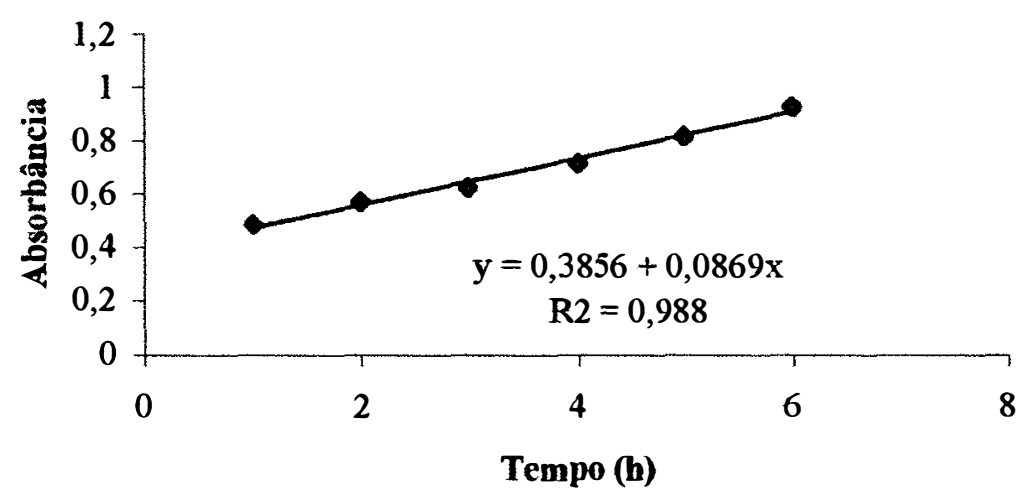

Figura 1 - Regressão linear para a fase exponencial da cinética de crescimento do isolado B118. 


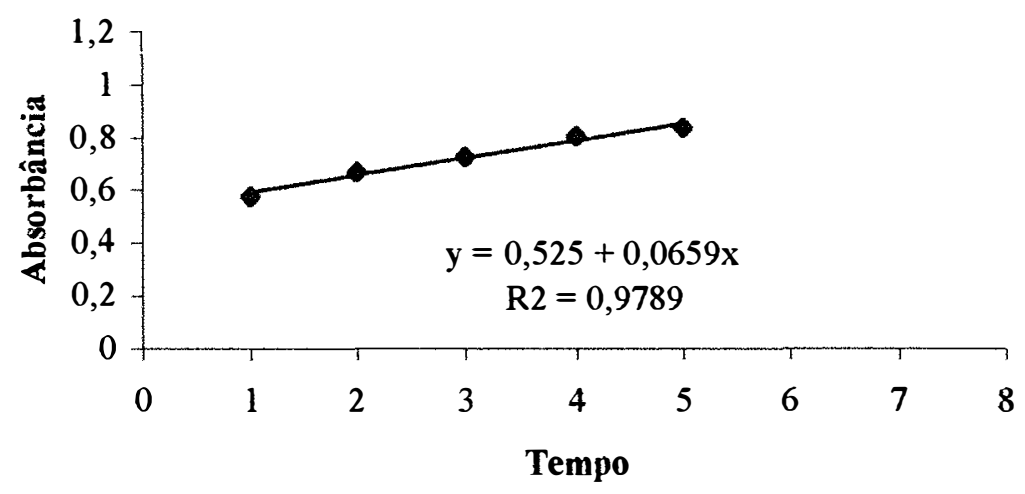

Figura 2 - Regressão linear para a fase exponencial da cinética de crescimento do isolado B119.

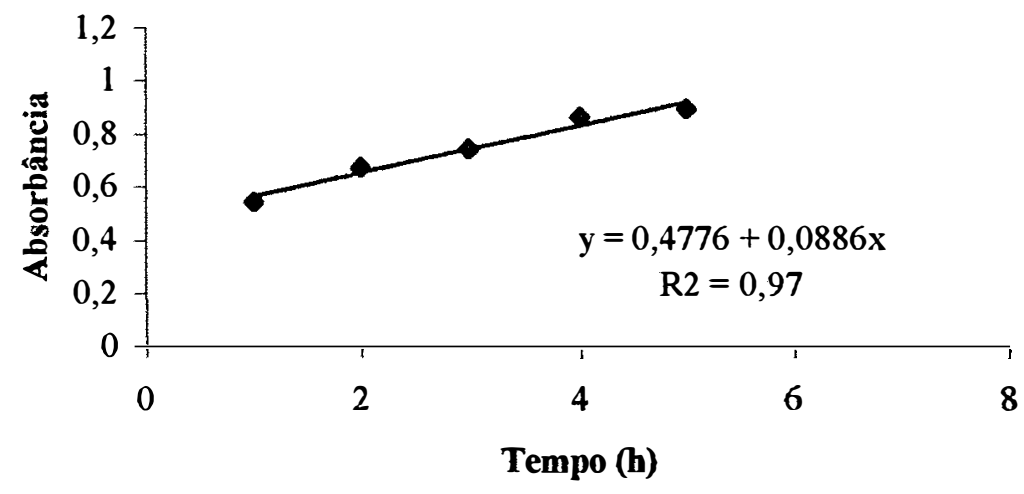

Figura 3 - Regressão linear para a fase exponencial da cinética de crescimento do isolado B120. 


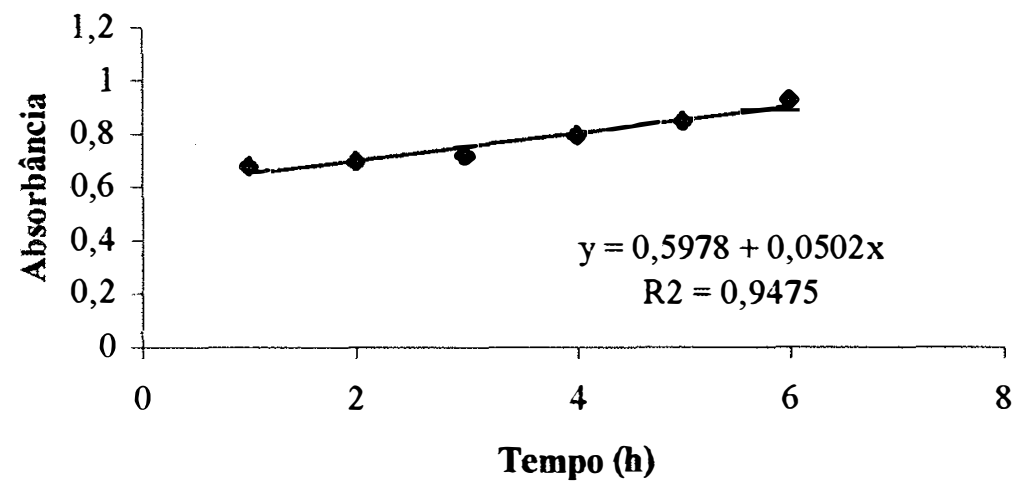

Figura 4 - Regressão linear para a fase exponencial da cinética de crescimento do isolado $\mathrm{B} 122$.

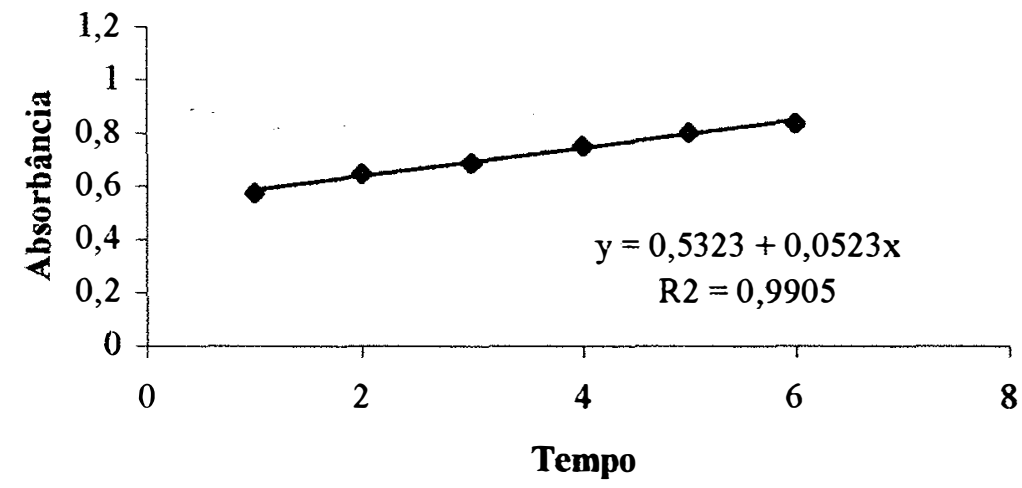

Figura 5 - Regressão linear para a fase exponencial da cinética de crescimento do isolado B134. 


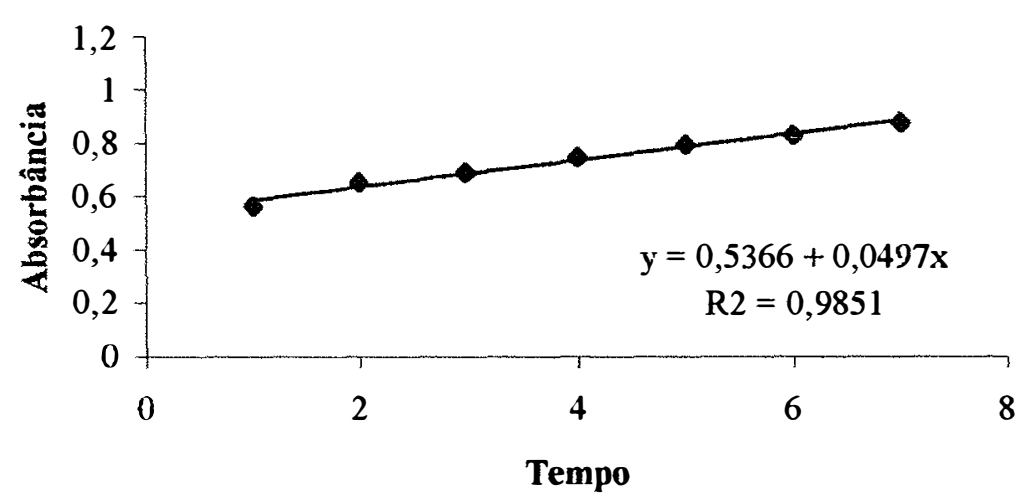

Figura 6 - Regressão linear para a fase exponencial da cinética de crescimento do isolado B151.

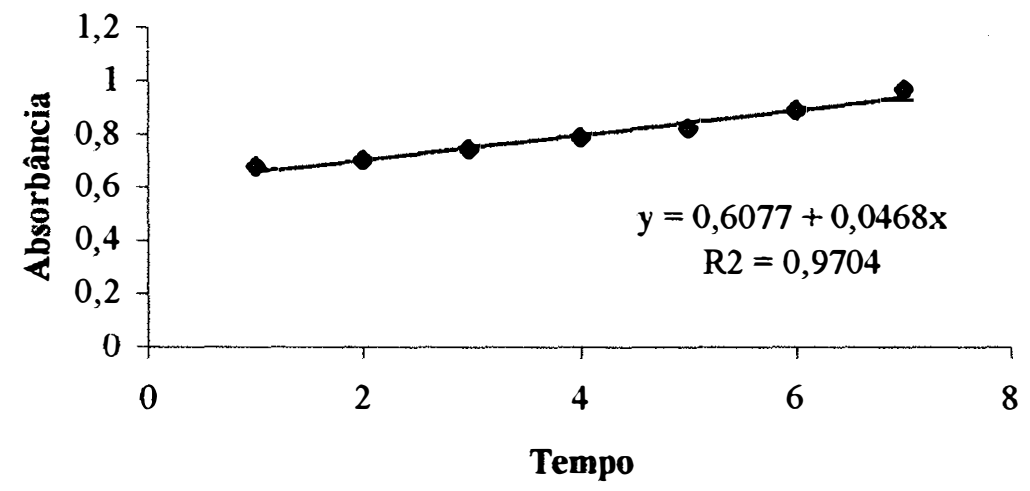

Figura 7 - Regressão linear para a fase exponencial da cinética de crescimento do isolado B152. 


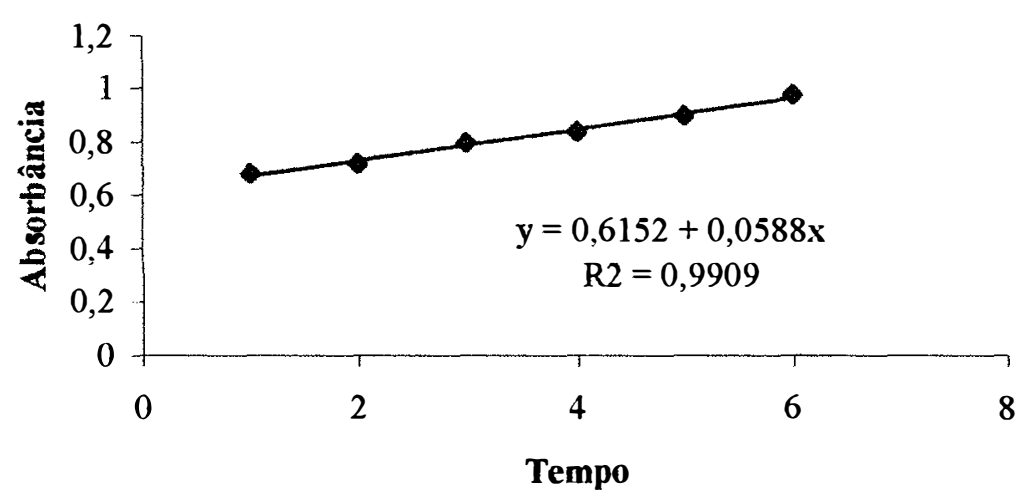

Figura 8 - Regressão linear para a fase exponencial da cinética de crescimento do isolado $\mathrm{B} 155$.

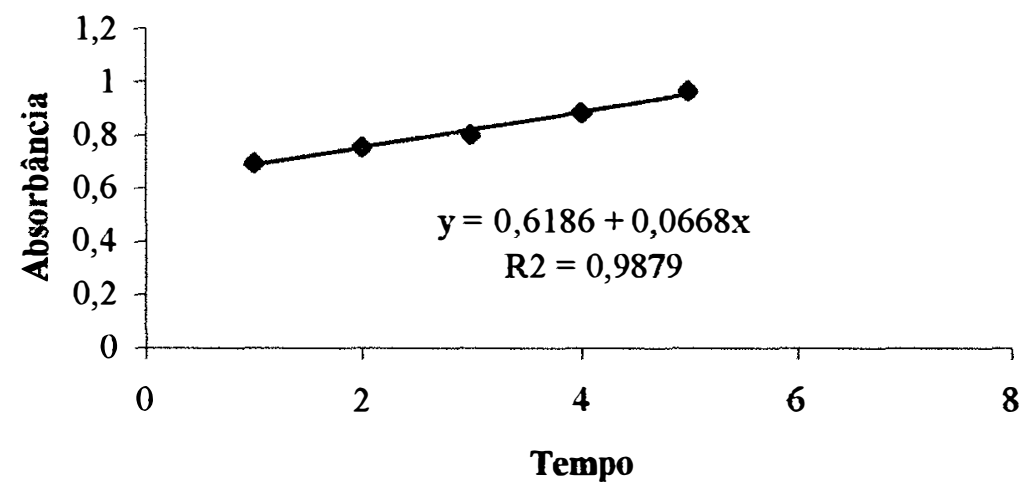

Figura 9 - Regressão linear para a fase exponencial da cinética de crescimento do isolado B156. 


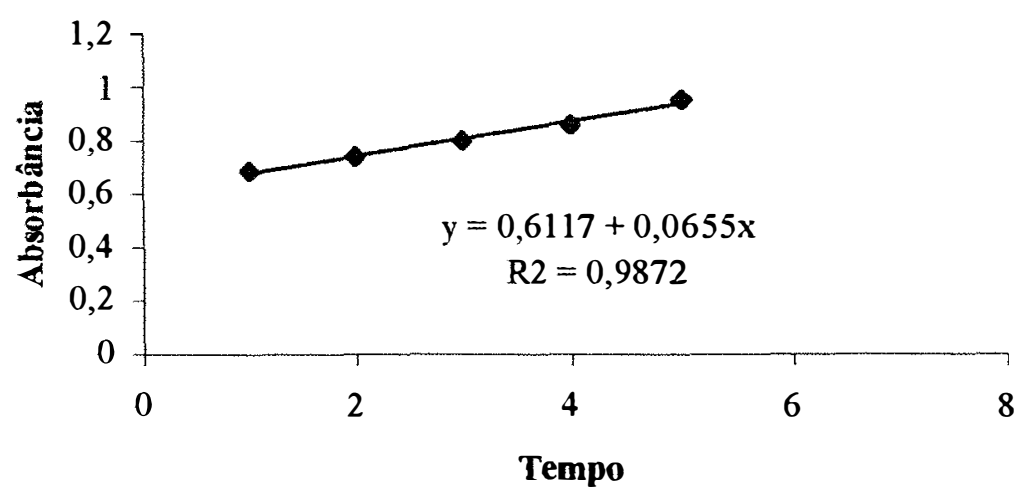

Figura 10 - Regressão linear para a fase exponencial da cinética de crescimento do isolado B157.

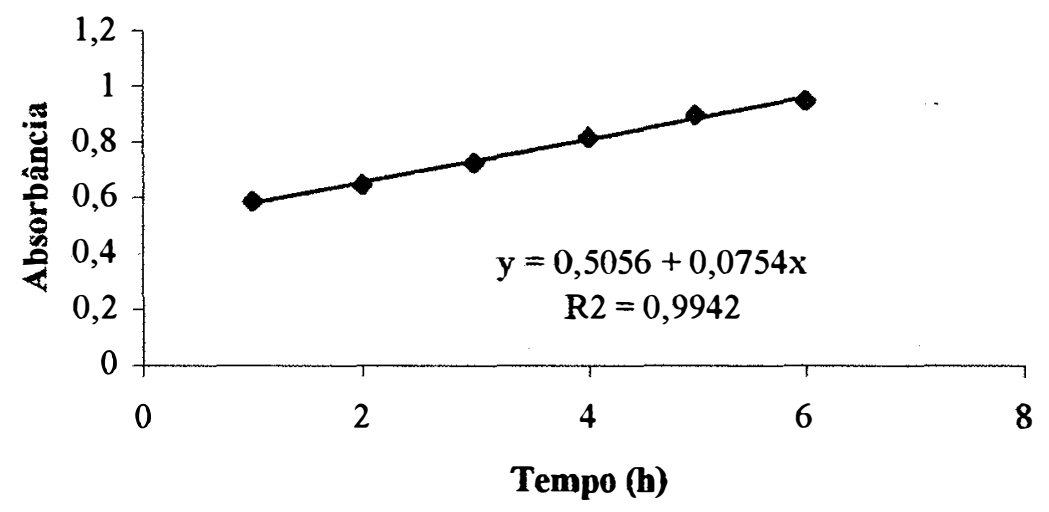

Figura 11 - Regressão linear para a fase exponencial da cinética de crescimento do isolado B174. 


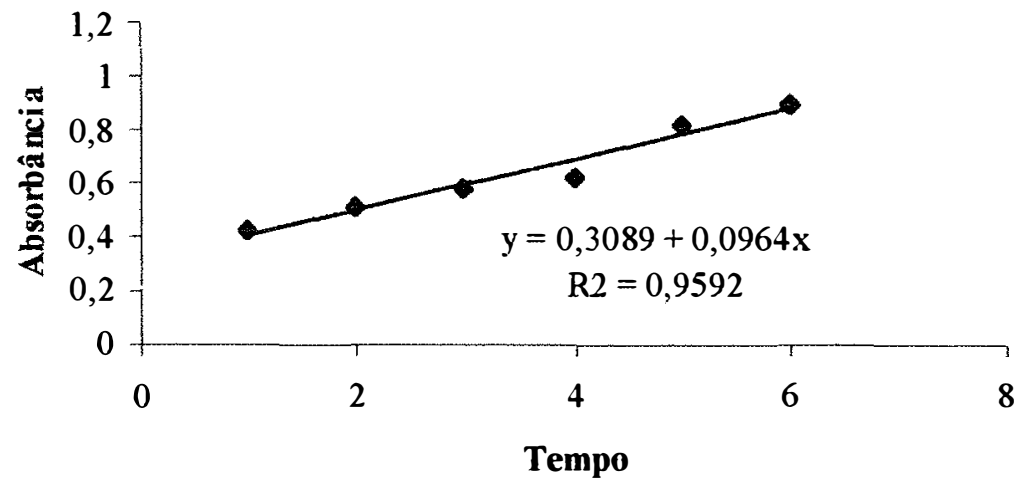

Figura 12 - Regressão linear para a fase exponencial da cinética de crescimento de Acinetobacter calcoaceticus RAG1.

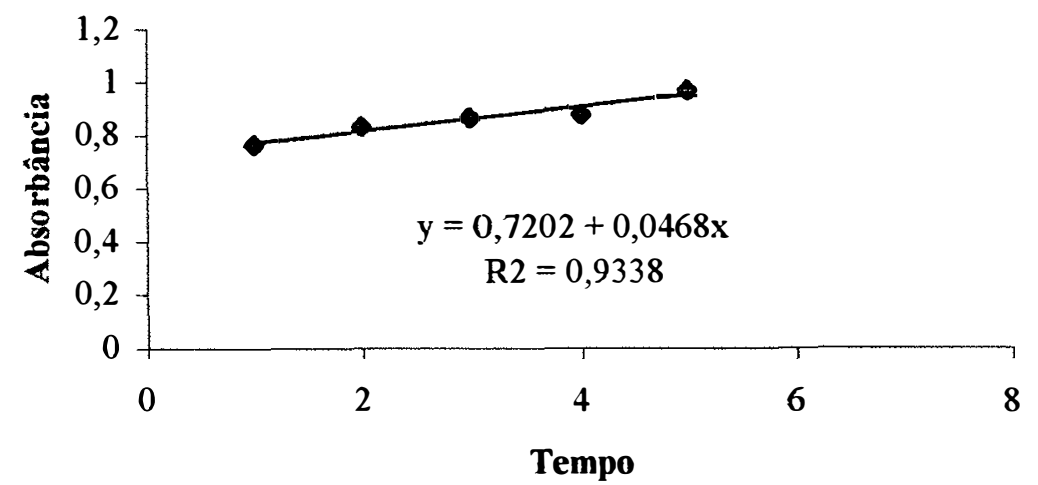

Figura 13 - Regressão linear para a fase exponencial da cinética de crescimento de Bacillus licheniformis. 


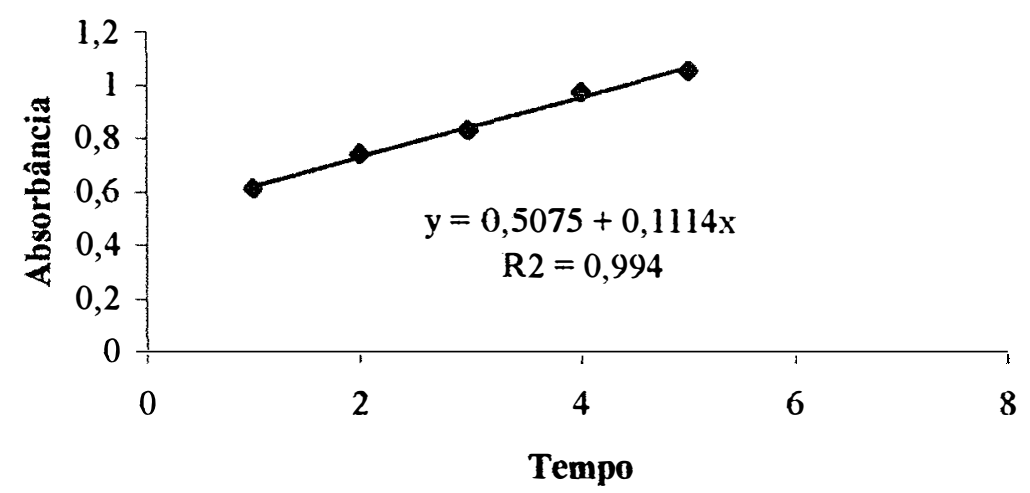

Figura 14 - Regressão linear para a fase exponencial da cinética de crescimento de Bacillus subtilis.

\subsection{Isolamento de plasmídios}

Nos 9 isolados (B118, B119, B120, B122, B134, B151, B152, B155 e B174) e nos microrganismos utilizados como padrões não houve visualização da presença de plasmídios, não sendo possível verificar a relação entre a presença de plasmídios e produção de substâncias emulsificantes (Anexo 1).

Reiser et al. (1993) revisaram recentemente que é conhecida a genética da expressão de compostos de superficie ativa. Foram encontrados 4 plamídios em $A$. calcoaceticus quando crescido em sedimento de óleo cru. A seleção de mutantes que perderam a capacidade de crescer em hidrocarbonetos, foi atribuída como sendo função de um desses plamídios, o pSR4. O plasmídio pSR4 de $20 \mathrm{~kb}$ de A. calcoaceticus $\mathrm{RA} 57$ é assumido como o codificador do fator associado à superficie das células. Contudo a biologia molecular neste campo é muito recente, a produção de linhagens mutantes e subseqüente isolamento dos genes envolvidos na biosíntese de biosurfactantes se tornará importante na tentativa de influenciar a regulação de mecanismos e modificar as vias de produção. 


\subsection{Atividade hemolítica}

Alguns autores sugerem a atividade hemolítica como teste para selecionar microrganismos produtores de biosurfactante. Foi realizado então o teste em placas de Petri com Ágar Sangue (Jain et al., 1992; Banat, 1993).

Nos isolados selecionados , B118, B119, B120, B122, B134, B151, B152, B155, B156, B157, B174 e nos padrões utilizados não foi verificada a formação de hemólise conforme demonstram as figuras 15, 16 e 17, indicando que o uso deste método rápido pode reduzir o número de linhagens selecionadas e podem ocorrer potenciais perdas de microrganismos com importante atividade.

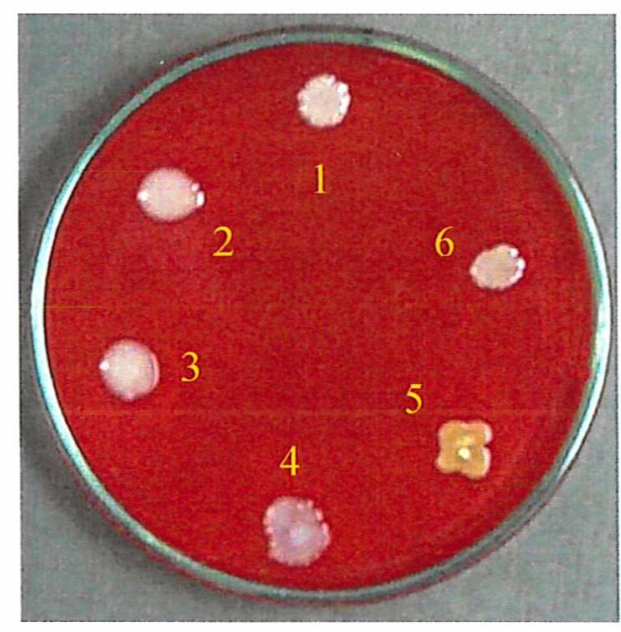

Figura 15 - Atividade hemolítica. Crescimento de colônias após 24 horas de incubação em placas de ágar-sangue. Colônia 1 - isolado B1 18; Colônia 2 - isolado B119; Colônia 3 - B120; Colônia 4 - B122; Colônia 5 - B134 e Colônia 6 $-\mathrm{B} 151$. 


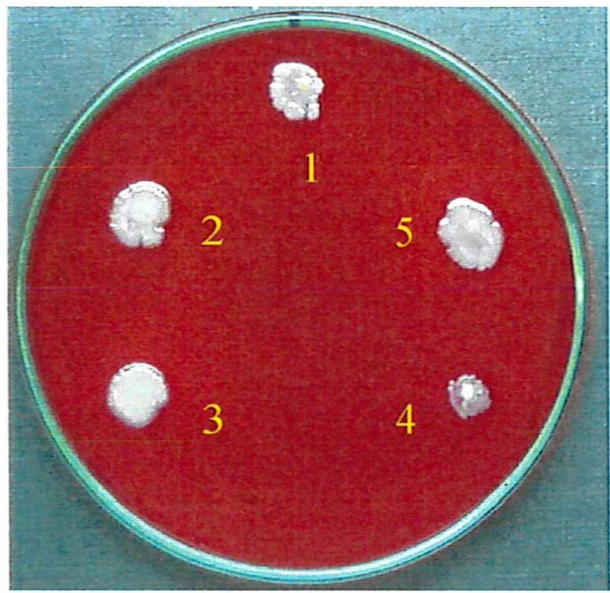

Figura 16 - Atividade hemolítica. Crescimento de colônias após 24 horas de incubação em placas de ágar-sangue. Colônia 1 - B152; Colônia 2 - B155; Colônia 3 B156; Colônia 4 - B157 e Colônia 5 - B174.

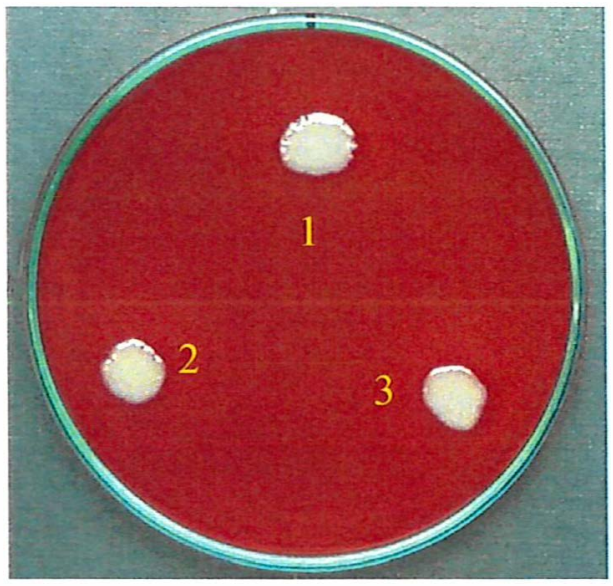

Figura 17 - Atividade hemolítica. Crescimento de colônias após 24 horas de incubação em placas de ágar-sangue. Colônia 1 - Acinetobacter calcoaceticus RAG1; Colônia 2-Bacillus licheniformis; Colônia 3-Bacillus subtilis. 
Nestes casos não foi possível a observação de halos de hemólise relacionados com o $\mathrm{IE}_{24} \mathrm{e}$ a atividade emulsificante, portanto, este método não mostrou relação com a produção de compostos emulsificantes, uma vez que os dados do índice de emulsificação e da atividade emulsificante apontam para isso.

\subsection{Coloração de Gram}

De acordo com a coloração os nove isolados bacterianos selecionados (B118, B119, B120, B122, B134, B151, B152, B155 e B174) apresentaram coloração Gram negativa.

Entre os microrganismos utilizados como padrões A. calcoaceticus RAG1 apresentou coloração Gram negativa e, B. licheniformis e B. subtilis apresentaram coloração Gram positiva (Anexo 1).

\subsection{Provas bioquímicas aplicadas à identificação de bactérias}

Utilizando-se a tabela de Pelczar Junior et al. (1997) para a diferenciação de espécies bacterianas através de testes bioquímicos, os isolados foram classificados como: B118 e B120 gênero Enterobacter, B119 gênero Morganella, B134 e B151 gênero Salmonella, B122, B152 e B155 gênero Citrobacter e B174 gênero Proteus. Os gêneros dos isolados identificados pertencem à família Enterobacteriaceae. Embora possam ser encontradas no meio ambiente natural, tais como em florestas, água, produtos de fazenda (vegetais) como microflora natural, a maioria habita os intestinos do homem e dos animais, seja como membros da microbiota normal ou como agentes de infecção (Trabulsi et al., 1999).

\subsection{Identificação de leveduras}

Os isolados $\mathrm{B} 156$ e $\mathrm{B} 157$ foram classificados como pertencentes ao gênero Hansenula da família Saccharomycetaceae. O gênero Hansenula está associado à 
deterioração de vegetais fermentados onde oxida o ácido acético e provoca alteração no sabor (Costa, 2002). Também são iniciadoras do processo de deterioração da silagem (Pereira \& Reis, 2002).

\subsection{Microscopia Eletrônica de Varredura}

As imagens referentes à microscopia eletrônica de varredura (MEV) se encontram nas figuras 18,19 e 20 .

Em todos os isolados e nos padrões utilizados não foi possível a visualização da formação de goma.

Os tamanhos variaram entre $1,2 \mu \mathrm{m}$ a $1,8 \mu \mathrm{m}$ entre as bactérias e, entre $4 \mu \mathrm{m} \mathrm{e}$ $5,8 \mu \mathrm{m}$ para as leveduras. As menores células foram do isolado B119 com $1,2 \mu \mathrm{m}$ e as maiores do isolado $\mathrm{B} 156 \mathrm{com} 5,8 \mu \mathrm{m}$.

O isolado B156 foi identificado como sendo a levedura Hansenula e na fotomicrografia possível a visualização da presença de um broto.

$\mathrm{O}$ formato predominante dos isolados de bactérias foi o de bacilo, variando somente o tamanho. As células de tamanhos variados podem ser visualizadas nas fotomicrografias que indicam as diferentes fases de crescimento pelos quais estão passando.

As fotomicrografias foram tiradas com aumento de 5000x para os isolados B119, B134, B151, B152, B156 e para os padrões A. calcoaceticus RAG1, B. licheniformis e B. subtilis. Somente a fotomicrografia do isolado B157 foi tirada com aumento de 2000x. 


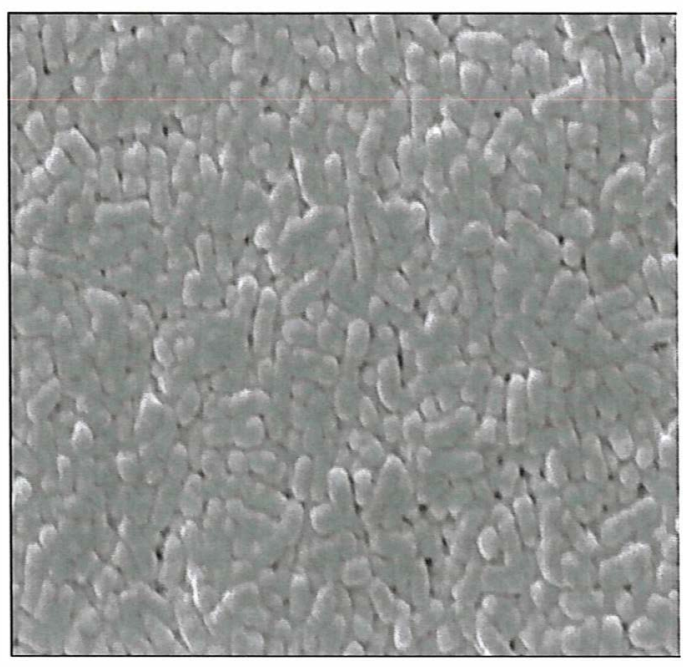

A

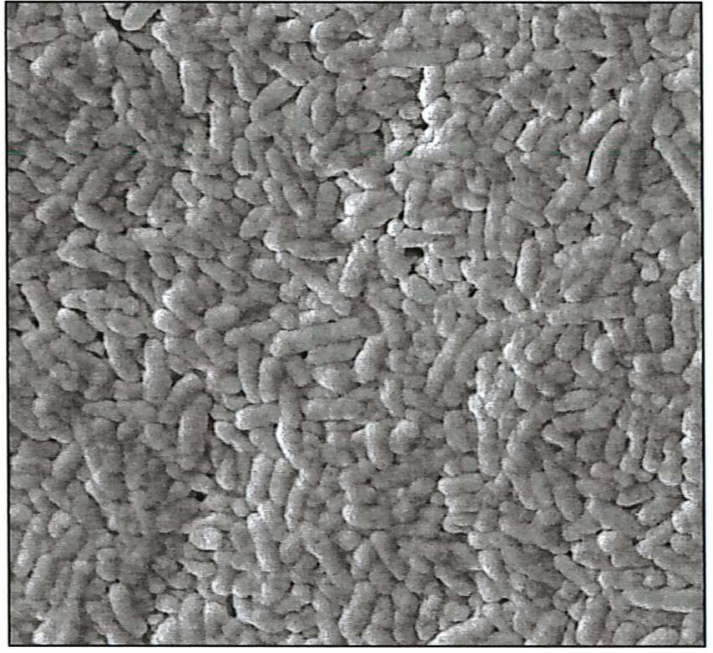

C

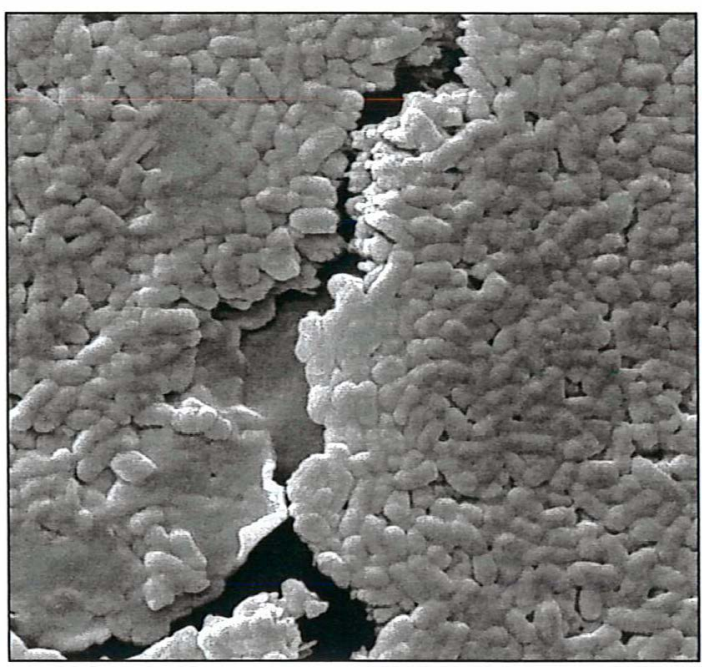

$\mathrm{B}$

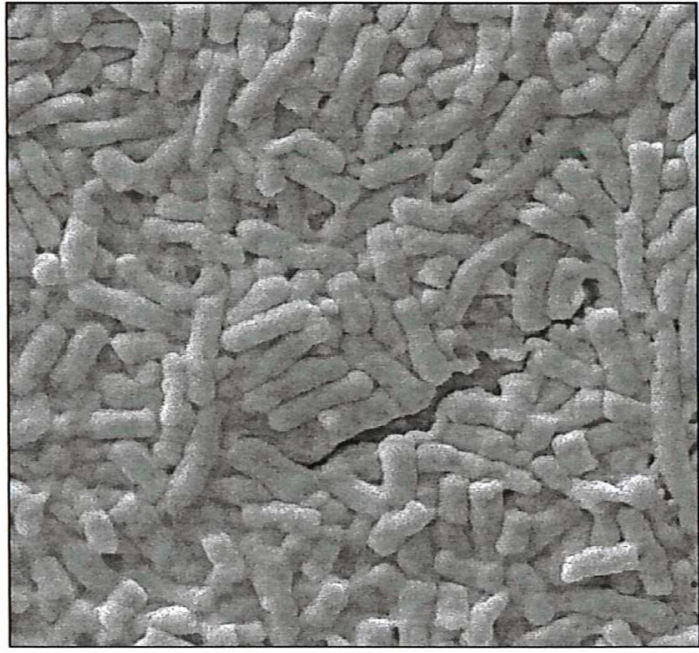

$\mathrm{D}$

Figura 18 - Fotomicrografia eletrônica de varredura dos isolados selecionados. $\mathrm{Na}$ figura A - isolado B119; figura B - isolado 134; figura C - isolado 151; figura D - isolado 152. Aumento 5000x. 


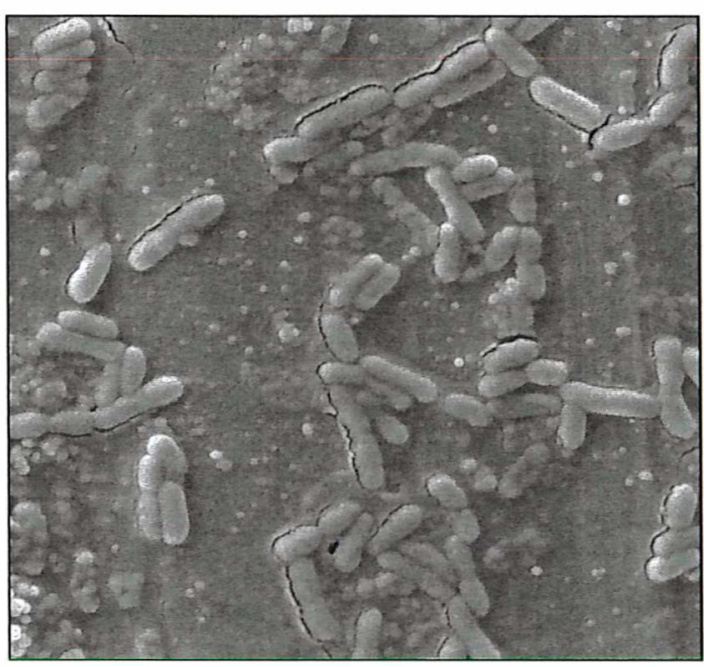

A

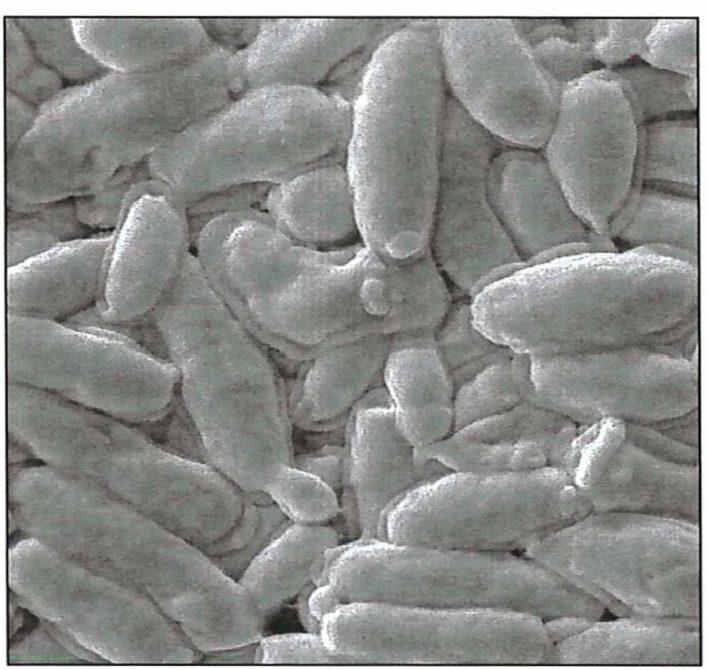

B

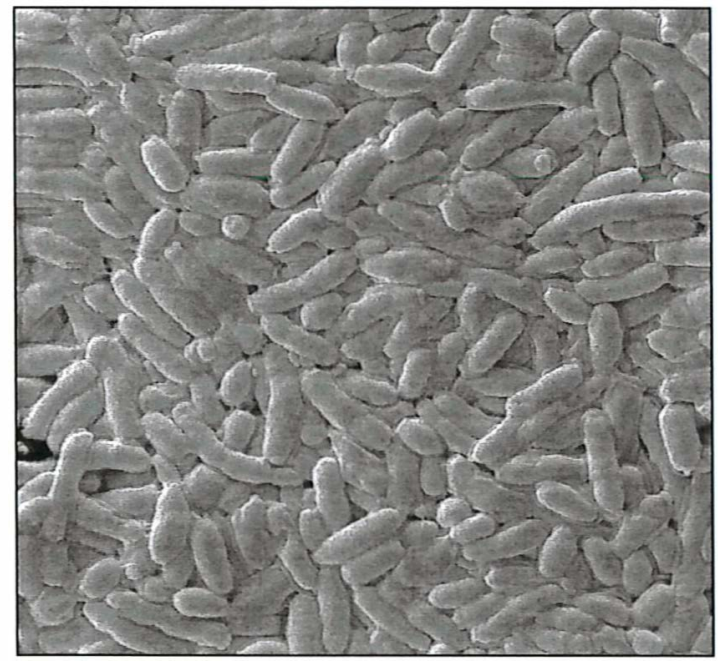

$\mathrm{C}$

Figura 19 - Fotomicrografia Eletrônica de Varredura dos isolados selecionados. Na figura A - isolado B155; B - isolado B156; C - isolado B157. Aumento $5000 x$, exceto B156 com aumento de 2000x. 


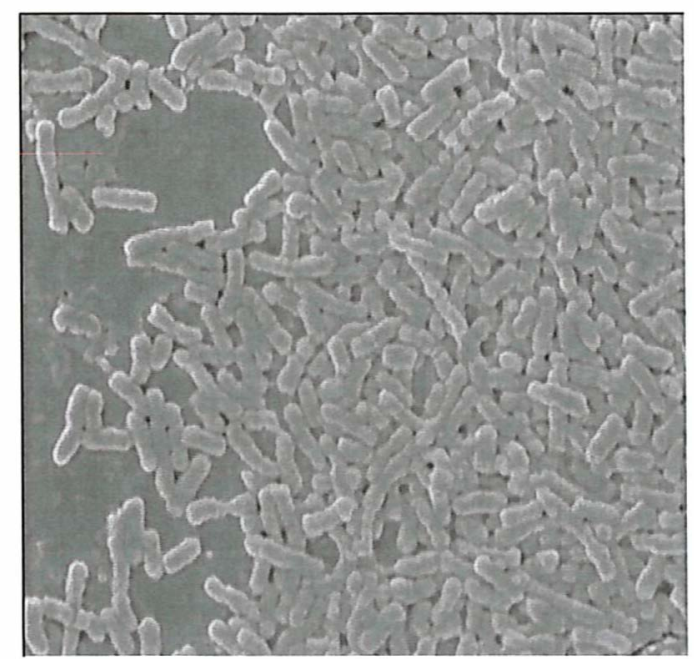

A

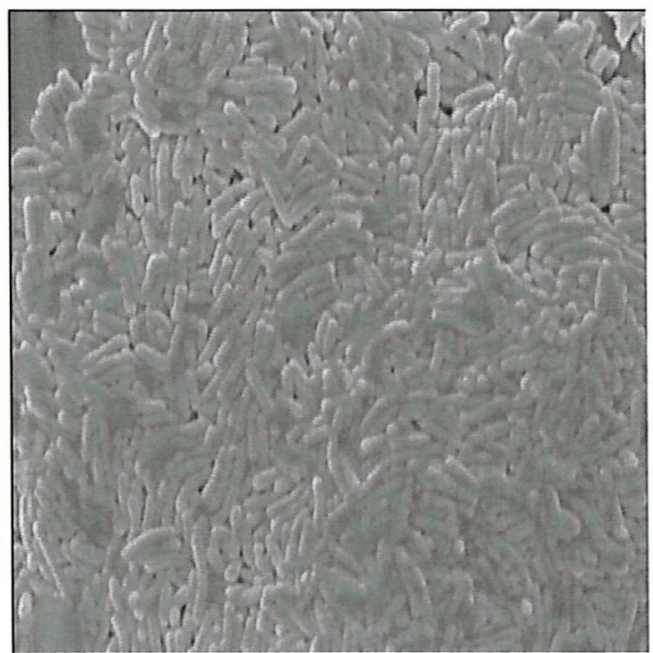

$\mathrm{B}$

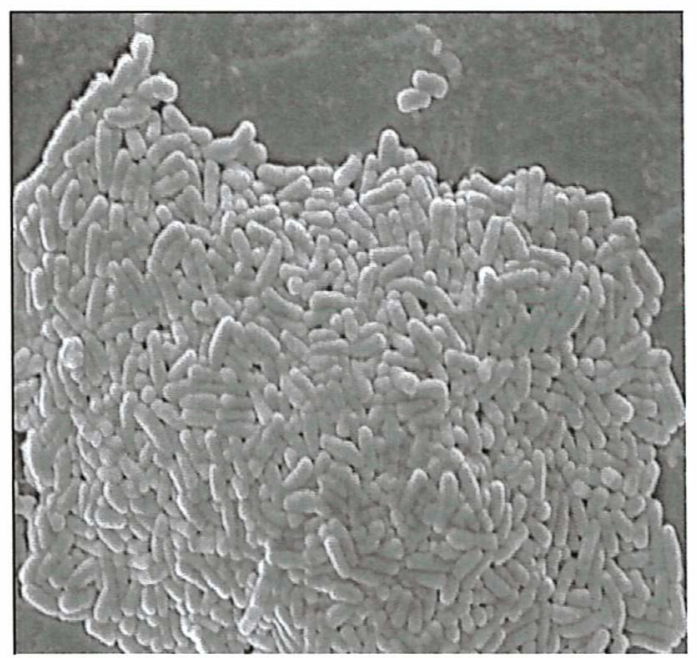

$\mathrm{C}$

Figura 20 - Fotomicrografia Eletrônica de Varredura dos padrões utilizados. Na figura A -Acinetobacter calcoaceticus RAG1; B - Bacillus licheniformis; C Bacillus subtilis. Aumento 5000x. 


\section{CONCLUSÕES}

Os métodos de isolamento, avaliação e seleção de microrganismos permitiram obter espécies com propriedades surfactantes que superam microrganismos comerciais e obtidos pela indústria. Estas espécies que foram identificadas poderão ser utilizadas para a produção de biosurfactantes, esperando-se coerência de resultados em maior escala, o que demanda estudos complementares. Algumas bactérias apresentam a propriedade de emulsificação e degradação de hidrocarbonetos, o que abre a possibilidade de várias aplicą̧ões industriais e de remedią̧ão de ambientes contaminados. Estudos complementares são necessários para a caracterização e quantificação direta dos biosurfactantes produzidos. Estudos são necessários para identificar e caracterizar as vias metabólicas e respectivas enzimas para a utilização de hidrocarbonetos pela célula. 
ANEXO: Resultados e caracterização dos isolados 


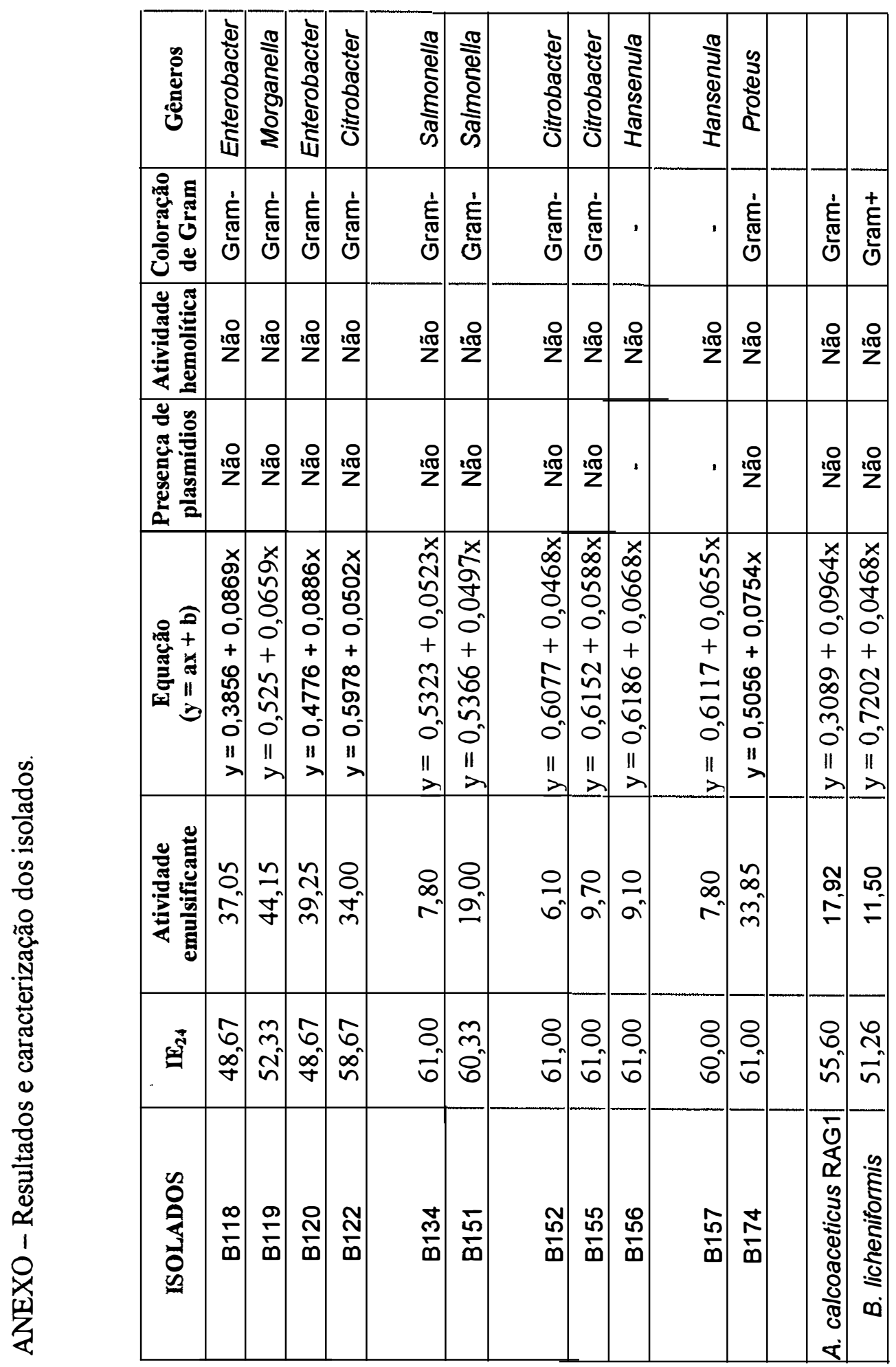




\section{REFERÊNCIAS BIBLIOGRÁFICAS}

ALEXANDER, M. Introduction to soil microbiology. 2.ed. New York: John Wiley, 1977. $467 \mathrm{p}$.

ALLSOPP, D.; SEAL, K.J. Introduction to biodeterioration. London: [s.n], 1986. $136 \mathrm{p}$.

ASHOK, B.T.; SAXENA, S.; MUSARRAT, J. Isolation and characterization of four polycyclic hydrocarbon degrading bacteria from soil near an oil refinery. Letters in Applied Microbiology, v.21, n.4, p.246-248, 1995.

ATLAS, R.M. Bioremediation of petroleum pollutants. International Biodeterioration \& Biodegradation, v.35, n.1-3, p.317-327, 1995.

BANAT, I.M. Biosurfactant production and possible uses in microbial enhanced oil recovery and oil pollution remediation: a review. Bioresource Technology, v.51, p.1-12, 1995.

BANAT, I.M. Characterization of biosurfactants and their use in pollution removal state of the art. Acta Biotechnology, v.15, p.251-267, 1995.

BANAT, I.M. The isolation of a thermophilic biosurfactant producing Bacillus sp. Biotechnology Letters, v. 15, p.591-594, 1993.

BANAT, I.M.; SAMARAH, N.; MURAD, M. Biosurfactant production and use in oil tank clean up. World Journal of Microbiology and Biotechnology, v.7, n.1, p.8088, 1991.

BARNETT, J.A.; PANKHURST, R.J. A new key to the yeasts. Amsterdan: American Elsevier Publishing CO., 1974. 273p.

BERTRAND, J.C. The potential application of biosurfactants in combating pollution in marine environments. Bioremediation, v. 141, n. 1, p.53-56, 1994. 
BLACKBURN, J.W.; HAFKER, W.R. The impact of biochemistry, bioavailability and bioactivity on the selection of bioremediation techniques. Trends in Biotechnology, v.11, p.328-333, 1993.

BOGNOLO, G. Biosurfactants as emulsifying agents for hydrocarbons Colloids and Surfaces: a physicochemical and engineering aspects, v.152, p.41-52, 1999.

BUSHNELL, C.D.; HAAS, H.F. The utilization of certain hydrocarbons by microorganisms. Journal of Bacteriology, v.41, n.2, p.653-673, 1941.

CARRILO, P.G.; MARDARAZ, C.; PITTA-ALVARAZ, S.I. Isolation and selection of biosurfactant-producing bacteria. World Journal of Microbiology \& Biotechnology, v.12, p.82-84, 1996.

CERNIGLIA, C.E. Microbial metabolism of polycyclic aromatic hydrocarbons. Advances in Applied Microbiology, v.30, p.31-71, 1984.

COLLINS, C.H.; LYNE, P.M. Microbiological methods. 4.ed. Londres: Butterworths \& Co, 1976. 521p.

COOPER, D.G.; GOLDENBERG, B.G. Surface-active agents from two Bacillus species. Applied Environmental Microbiology, v.53, p.224-229, 1987.

COOPER, D.G. Biosurfactants. Microbiological Sciences, v.3, n.5, p.145-149, 1986.

COOPER, D.G.; ZAJIC, J.E. Surface-active compounds from microorganisms. Advances in Applied Microbiology, v.26, p.229-253, 1980.

COSTA, A.S. Os microrganismos e os alimentos. http:// www livronline com/cursos/gratuitos/MA002/capitulos/cap4.htnll (02 dez. 2002)

COSTA, J.A.T.B. Universidade de Santa Maria Físico-Química http://wi3.ufsm. br/juca/tensao.htm (25 nov. 2002)

FIECHTER, A. Biosurfactants: moving towards industrial application. Trends in Biotechnology, v.10, p.208-217, 1992.

GUERRA-SANTOS, L.; KAPPELI, O; FIECHTER, A. Pseudomonas aeruginosa biosurfactant production in continuous culture with glucose as carbon source. Applied and Environmental Microbiology, v.48, p.301-301, 1994.

GUTNICK, D.L.; ROSEMBERG, E. Oil tankers and pollution: a microbiological approach. Annual Reviews in Microbiology, v.31, p.379-396, 1977. 
HOMMEL, R.K. Formation and physiological role of biosurfactants produced by hydrocarbon-utilizing microorganisms. Biodegradation, v.1, p.107-119, 1990.

HOROWITZ, S.; GILBERT, J.N.; GRIFFIN, W.M. Isolation and characterization of a surfactant produced by Bacillus licheniformis $86 . \quad$ Journal Industrial Microbiology, v.6, p.243-248, 1990.

JAIN, D.K; COLLINS-THOMPSON, D.L.; LEE, H. A drop-collapsing test for screening surfactant-producing microorganisms. Journal of Microbiological Methods, v.13, p.271-279, 1992.

JENEIL BIOSURFACTANT COMPANY. Applications areas. http://biosurfactant.com (02 Dec. 2002)

KITAJMA, E.W.; LEITE, B. Curso introdutório de Microscopia Eletrônica de Varredura. 2.ed. Piracicaba: ESALQ, 1999. 46p.

MCGILL, W.B.; ROWELL, M.J.; WESTLAKE, D.W.S. Biochemistry, ecology and microbiology of petroleum components in soil. In: PAUL, E.A.; LAND, J.N. Soil Biochemistry, v.5, p. 22-296, 1981.

MERCADÉ, M.E; MONLEÓN, L.; ANDRÉS, C. Screening and selection of surfactant-producing bacteria from waste lubrificating oil. Journal of Applied Bacteriology, v.81, p.161-166, 1996:

MORTON, L.H.G.; GILLATT, J.W.; WARRILOW, E.O. A potential method for the recognition of metal working fluid spoilage organisms. International Biodeterioration Bulletin, v.19, n.2, p.39-43, 1983.

MURIEL, J.M.; BRUQUE, J.M.; OLÍAS, J.M. Production of biosurfactants by Cladosporium resinae. Biotechnology Letters, v. 18, n.3, p.235-240, 1996.

NEU, T.R.; MAY, M. Significance of bacterial surface-active compounds in interaction of bacteria with interfaces. Microbiological Reviews, v.60, p.151-166, 1996.

PELCZAR JUNIOR, M.J.; CHAN, E.C.S.; KRIEG, N.R. Microbiologia: conceitos e aplicações. 2.ed. São Paulo: Makron Books do Brasil, 1997. 524p.

PEREIRA, J.R.A.; REIS, R.A. Produção e utilização de forragem pré-secada http://www.nucleoestudo.ufla.br/nefor/anais/Palestra08.pdf (02 dez. 2002) 
PINES, O.; BAYER, E.A.; GUTNICK, D.L. Localization of emulsan-like polymers associated with the cell surface of Acinetobacter calcoaceticus RAG-1. Journal of Bacteriology, v.154, p.893-898, 1983.

PIPES, W.O. Microbiology of active sludge bulking. Advances in Applied Microbiology, v.24, p.85-127, 1978.

PRUTHI, V.; CAMEOTRA, S.S. Rapid meted for monitoring maximum biosurfactant production obtained by acetone precipitation. Biotechnology Techniques, v.9, p.271-276, 1995.

RATLEDGE, C. Hydrocarbons: products of hydrocarbon-microorganism interaction. Biodeterioration, v.7, p.219-236, 1988.

REISER, J.; KOCH, A.K.; OCHSNER, U.A.; FIECHTER, A. Genetics of surfaceactive compounds. In: REISER, J.; KOCH, A.K.; OCHSNER, U.A.; FIECHTER, A. Biosurfactants: production-properties-application. New York: N. Kosaric, 1993. cap.8, p.231-249.

RODRIGUEZ, E.G.C; MENEZES, E.P.; SANTANA, L.M.M. Oil degrading microorganisms. In: LATIN AMERICAN BIODETERIORATION SYMPOSIUM, 2., Porto Alegre, 1996, Anais. Porto Alegre: UFRGS, 1996. p. 144.

ROSATO, Y.B. Biodegradação do petróleo. In: MELO, I.S.; AZEVEDO, J.L. Microbiologia ambiental. Jaguariúna: Embrapa, 1997. cap.14, p.307-334.

ROSEMBERG, E. Microbial surfactants. CRC Critical Reviews in Biotechnology, v.3, p.109-132, 1986.

ROSEMBERG, E.; ZUCKERBERG， A.; RUBINOVITZ， C.; GUTNICK， D.L. Emulsifier of Arthrobacter RAG-1: isolation and emulsifying properties. Applied Environmental Microbiology, v.37, p.402-408, 1979.

RUBNOVITZ, C.; GUTINICK, D.L.; ROSEMBERG, E. Emulsan production by Acinetobacter calcoaceticus RAG-92 in the presence of chloranphenicol. Journal of Bacteriology, v.161, p.126-131, 1982.

SAKER, A.K.; GOURDAUD, J.C.; SHARMA, M.M.; GEORGIOU, G. A critical evaluation of MEOR processes. In Situ, v.13, p.207-238, 1989. 
SHEPHERD, R.; ROCKEY, J.; SUTHERLAND, I.; ROLLER, S. Novel bioemulsifiers from microorganisms for use in foods. Journal of Biotechnology, v.40, p.207-217, 1995.

SHOHAM, Y.; ROSEMBERG, M.; ROSEMBERG, E. Bacterial degradation of Emulsan. Applied Environmental Microbiology, v.46, p.573-579, 1983.

SILVA, N.; JUNQUEIRA, V.C.A.; SILVEIRA, N.F.A. Manual de métodos de análise microbiológica de alimentos. São Paulo: Livraria Varela, 1997. 295p.

TRABULSI, L.R.; ALTERTHUM, F.; GOMPERTZ, O.F.; CANDEIAS, J.A.N. Microbiologia. São Paulo: Editora Atheneu, 1999. cap.3, p.119-329: Bacteriologia Médica.

WASKO, J.D; BRATT, R.P. Properties of a biosurfactant produced by the fuel contaminant Ochrobactrum anthropii. International Biodeterioration, v.27, n.3, p.265-273, 1990.

WILSON, S.C.; JONES, K.C. Bioremediation of soil contamined with polynuclear aromatic hydrocarbons (PAHs). Environmental Pollution, v.81, p.229-249, 1993.

VANNI, S. M. Modelos de regressão: estatística aplicada. São Paulo: Legnar Informática, 1998. 177p.

ZAJIC, J.E.; SEFFENS, W. Biosurfactants. Critical Reviews in Biotechnology, v.l, p.87-107, 1984. 
APÊNDICES 
APÊNDICE 1 - Meios de cultura, soluções e reagentes.

\subsection{Meio mineral (Rosemberg et al., 1979)}

Fosfato monobásico de sódio - 1,83\%; Fosfato dibásico de sódio - 0,6\%; Sulfato de amônio - 0,4\%; Sulfato manganoso - 0,02\%; Etanol - 2\%; Querosene - 2\% Água d.d. $1000 \mathrm{~mL}$. Esterilizado por autoclavagem a 1 atm por 20 minutos. $\mathrm{O}$ etanol foi adicionado após a autoclavagem.

\subsection{Meio mineral (Rosemberg et al., 1979) sólido com glicose}

Fosfato monobásico de sódio - 1,83\%; Fosfato dibásico de sódio - 0,6\%; Sulfato de amônio - 0,4\%; Sulfato manganoso - 0,02\%; Etanol - 2\%; Querosene - 2\% Água d.d. $1000 \mathrm{~mL}$. Esterilizado por autoclavagem a 1 atm por 20 minutos. Para meio sólido acrescentou-se $2 \%$ de ágar e $2 \%$ de glicose.

\subsection{Meio mineral 10x concentrado para suplementação}

Fosfato monobásico de sódio - 18,3\%; Fosfato dibásico de sódio - 6\%; Sulfato de amônio - 4\%; Sulfato manganoso - 0,2\%. Esterilizado por autoclavagem a 1 atm por 20 minutos.

\subsection{Meio YEPD}

Extrato de levedura - 1\%; Peptona - 2\%; Dextrose - 1\%; Ágar - 2\%; Água d.d. $1000 \mathrm{~mL}$. Esterilizado por autoclavagem a 1 atm por 20 minutos.

\section{5 Ágar sangue}

Ágar sangue - 4\%; Água d.d. - 1000mL. Esterilizado por autoclavagem a 1 atm por 20 minutos. Depois de resfriado até cerca de 45 a $50^{\circ} \mathrm{C}$ adicionar homogeneamente de 5 a $8 \%$ de sangue estéril. A formação de bolhas deve ser evitada.

\subsection{Solução de glicerol $30 \%$}

Glicerol - 30\% (p/v). Em água d.d. 


\subsection{Corante rosa bengala para o teste do Índice de Emulsificação ( $\left.\mathrm{IE}_{24}\right)$}

Corante rosa bengala $-0,1 \%$. Em água d.d. Dissolver bem o corante em água destilada. Armazenar em frasco âmbar.

1.8 Tampão de reação para atividade emulsificante (Rosemberg et al., 1979) 20mM Tris-HCL (pH 7.0); $10 \mathrm{mM}$ sulfato de magnésio. Preparar na hora de usar.

\subsection{Solução solvente para o teste da atividade emulsificante (Rosemberg et al.,} 1979)

Hexadecano $-7 \mathrm{~mL} ; 2$ Metilnaftaleno - 5g. Preparar na hora de usar.

\subsection{Caldo indol}

Triptona - 5g; Cloreto de sódio - 5g; Água d.d. - 1000mL. Autoclavar a $1 \mathrm{~atm}$ por 15 minutos.

\subsection{Meio de Clark e Lubs}

Peptona - 5g; Fosfato dibásico de potássio - 5g; Glicose - 5g; Água d.d. - 1000mL. Autoclavar a latm por 15 minutos.

\subsection{Meio Mili}

Extrato de levedura - 3g; Peptona - 10g; Triptona - 10g; L-lisina - 10g; Glicose - 1g; Púrpura de bromocresol - $10 \mathrm{~mL}$ da solução pronta 0,2\%; Ágar - 2g; Água d.d. $1000 \mathrm{~mL}$. Autoclavar a $1 \mathrm{~atm}$ por 15 minutos.

\subsection{Bismuto sulfito ágar}

Extrato de carne - 5g; Peptona - 10g; Glicose - 5g; Hidrogeno fosfato de sódio $-4 \mathrm{~g}$; Sulfato de ferro II - 0,3g; Verde brilhante - 0,025g; Indicador bismuto sulfito - $8 \mathrm{~g}$; Ágar - 15g; Água d.d. - 1000mL. Autoclavar a 1 atm por 15 minutos. 


\subsection{Urea Agar base}

Uréia - 20g; Peptona - 10g; Glicose - 10g; Cloreto de sódio - 50g; Fosfato monobásico de potássio - 20g; Vermelho de fenol - 0,012g; Ágar - 15g; Água d.d. - 1000mL. Não autoclavar. Filtrar em Millipore.

\subsection{5 Ágar leite}

Triptona - 5g; Extrato levedura - 2,5g; Glicose - 1g; Cloreto de sódio - 25g; Ágar $15 \mathrm{~g}$; Leite esterilizado $-10 \mathrm{~mL}$; Água d. d. $-1000 \mathrm{~mL}$. Esterilizar o meio a $1 \mathrm{~atm}$ por 15 minutos sem o leite. O leite deve ser adicionado após a autoclavagem.

\subsection{Caldo lactosado}

$13 \mathrm{~g}$ do meio de cultura desidratado; Água d. d. $-1000 \mathrm{~mL}$. Autoclavar a $1 \mathrm{~atm}$ por 15 minutos.

\subsection{Caldo simples}

Extrato de levedura - 10g; Peptona - 10g; Dextrose - 20g; Água d.d. - 1000mL. Autoclavar a $1 \mathrm{~atm}$ por 15 minutos.

\subsection{Caldo nutriente}

Triptona - 10g; Cloreto de sódio - 10g; Extrato de levedura - 5g; Ágar - 15g; Água d.d. $-1000 \mathrm{~mL}$. Autoclavar a $1 \mathrm{~atm}$ por 15 minutos.

\subsection{9 Ágar citrato Simmons}

Fosfato monobásico de amônio - 1g; Fosfato dibásico de potássio - 1g; Cloreto de sódio - 5g; Citrato de sódio - 2g; Sulfato de magnésio - 0,2g; Azul de bromotimol - 0,08g; Ágar - 13g; Água d.d. - 1000mL. Autoclavar a 1atm por 15 minutos.

\subsection{Nutriente ágar}

Extrato de carne - 3g; Bacto-peptona - 5g; Ágar - 15g; Água d.d. - 1000mL. Autoclavar a $1 \mathrm{~atm}$ por 15 minutos. 


\subsection{Meio de gelatina}

Bacto-gelatina - 120g; Água d.d. - 1000mL. Autoclavar a $1 \mathrm{~atm}$ por 15 minutos.

\subsection{Solução de alfa naftol}

Alfa naftol - 5g; Etanol - 100mL. Dissolver $5 \mathrm{~g}$ de alfa naftol em 90mL de etanol. Completar o volume para $100 \mathrm{~mL}$.

\subsection{Reativo de Barrit}

Hidróxido de potássio - 40g; Água d.d. - 100mL. Dissolver 40g de hidróxido de potássio em $60 \mathrm{~mL}$ de água dd. Completar o volume para $100 \mathrm{~mL}$.

\subsection{4 Óleo mineral (marca comercial Nujol)}

O óleo mineral foi colocado em um erlenmeyer e esterilizado por autoclavagem a latm por 15 minutos.

\subsection{Solução de cristal-violeta}

Dissolver $0,5 \mathrm{~g}$ de cristal-violeta em $100 \mathrm{~mL}$ de água destilada. Armazenar em frasco protegido de luz, renovar semanalmente e filtrar para retirar impurezas.

\subsection{Solução de iodo}

Dissolver $2 \mathrm{~g}$ de iodeto de potássio e $1 \mathrm{~g}$ de iodo em $20 \mathrm{~mL}$ de água destilada. Completar o volume para $100 \mathrm{~mL}$. Armazenar em frasco protegido de luz, renovar semanalmente e filtrar para retirar impurezas.

\subsection{Solução de safranina}

Dissolver $1 \mathrm{~g}$ de safranina em $100 \mathrm{~mL}$ de água destilada. Armazenar em frasco protegido de luz, renovar semanalmente e filtrar para retirar impurezas. 
APÊNDICE 2 - Valores do índice de emulsificação $\left(\mathrm{IE}_{24}\right)$ para os cultivos dos 161 isolados em meio mineral tendo como fonte de carbono $2 \%$ de etanol. Os valores representam 3 repetições para cada isolado.

\begin{tabular}{|c|c|c|c|c|}
\hline ISOLADOS & Exp.1 (\%) & Exp. 2 (\%) & Exp. 3 (\%) & Média \\
\hline A. calcoaceticus RAG1 & 53,50 & 64,00 & 60,00 & 59,17 \\
\hline B. licheniformis & 53,50 & 52,00 & 54,00 & 53,17 \\
\hline B. subtilis & 53,50 & 28,00 & 58,00 & 46,50 \\
\hline B03 & 57,00 & 64,00 & 40,00 & 53,67 \\
\hline B05 & 57,00 & 60,00 & 56,00 & 57,67 \\
\hline B07 & 54,00 & 60,00 & 40,00 & 51,33 \\
\hline B08 & 61,00 & 60,00 & 48,00 & 56,33 \\
\hline B09 & 61,00 & 60,00 & 56,00 & 59,00 \\
\hline B10 & 57,10 & 64,00 & 60,00 & 60,37 \\
\hline B11 & 57,10 & 60,00 & 60,00 & 59,03 \\
\hline B13 & 57,10 & 56,00 & 56,00 & 56,37 \\
\hline B14 & 53,50 & 60,00 & 56,00 & 56,50 \\
\hline B15 & 57,10 & 40,00 & 60,00 & 52,37 \\
\hline B16 & 57,10 & 56,00 & 60,00 & 57,70 \\
\hline B17 & 57,10 & 56,00 & 64,00 & 59,03 \\
\hline B18 & 46,40 & 60,00 & 64,00 & 56,80 \\
\hline B20 & 57,10 & 60,00 & 56,00 & 57,70 \\
\hline B21 & 57,10 & 56,00 & 28,00 & 47,03 \\
\hline B22 & 46,40 & 68,00 & 64,00 & 59,47 \\
\hline B23 & 35,70 & 52,00 & 52,00 & 46,57 \\
\hline B24 & 50,00 & 40,00 & 40,00 & 43,33 \\
\hline
\end{tabular}


APÊNDICE 3 - Valores do índice de emulsificação $\left(\mathbb{E}_{24}\right)$ para os cultivos dos 161 isolados em meio mineral tendo como fonte de carbono $2 \%$ de etanol. Os valores representam 3 repetições para cada isolado.

\begin{tabular}{|c|c|c|c|c|}
\hline ISOLADOS & \multicolumn{5}{|c|}{ Exp.1 (\%) } & Exp. 2 (\%) & Exp. 3 (\%) & Média \\
\hline A. calcoaceticus RAG1 & 60,00 & 56,00 & 60,00 & 58,67 \\
\hline B. licheniformis & 40,00 & 48,00 & 52,00 & 46,67 \\
\hline B. subtilis & 60,00 & 48,00 & 52,00 & 53,33 \\
\hline B25 & 54,00 & 50,00 & 60,00 & 54,67 \\
\hline B26 & 46,00 & 64,00 & 60,00 & 56,67 \\
\hline B27 & 57,00 & 64,00 & 60,00 & 60,33 \\
\hline B28 & 57,00 & 60,00 & 56,00 & 57,67 \\
\hline B29 & 57,00 & 64,00 & 60,00 & 60,33 \\
\hline B30 & 57,00 & 60,00 & 60,00 & 59,00 \\
\hline B31 & 50,00 & 60,00 & 56,00 & 55,33 \\
\hline B33 & 54,00 & 52,00 & 40,00 & 48,67 \\
\hline B34 & 50,00 & 52,00 & 28,00 & 43,33 \\
\hline B35 & 57,00 & 56,00 & 40,00 & 51,00 \\
\hline B36 & 50,00 & 44,00 & 56,00 & 50,00 \\
\hline B37 & 50,00 & 60,00 & 40,00 & 50,00 \\
\hline B38 & 57,00 & 60,00 & 48,00 & 55,00 \\
\hline B39 & 54,00 & 56,00 & 56,00 & 55,33 \\
\hline B40 & 54,00 & 60,00 & 52,00 & 55,33 \\
\hline B41 & 61,00 & 52,00 & 60,00 & 57,67 \\
\hline B42 & 57,00 & 40,00 & 40,00 & 45,67 \\
\hline B43 & 57,00 & 40,00 & 40,00 & 45,67 \\
\hline B44 & 54,00 & 40,00 & 24,00 & 39,33 \\
\hline B46 & 57,00 & 56,00 & 40,00 & 51,00 \\
\hline B47 & 54,00 & 48,00 & 48,00 & 50,00 \\
\hline B48 & 54,00 & 40,00 & 56,00 & 50,00 \\
\hline B49 & 54,00 & 60,00 & 77,00 & 63,67 \\
\hline B51 & 54,00 & 40,00 & 52,00 & 48,67 \\
\hline & & & & \\
\hline
\end{tabular}


APÊNDICE 4 - Valores do índice de emulsificação $\left(\mathbb{E}_{24}\right)$ para os cultivos dos 161 isolados em meio mineral tendo como fonte de carbono $2 \%$ de etanol. Os valores representam 3 repetições para cada isolado.

\begin{tabular}{|c|c|c|c|c|}
\hline ISOLADOS & $\operatorname{Exp.1}(\%)$ & Exp. $2(\%)$ & Exp. $3(\%)$ & Média \\
\hline A. calcoacelicus $\mathrm{RAG1}$ & 64,00 & 60,00 & 58,00 & 60,67 \\
\hline B. licheniformis & 52,00 & 40,00 & 48,00 & 46,67 \\
\hline B. subtilis & 28,00 & 60,00 & 58,00 & 48,67 \\
\hline B52 & 58,00 & 40,00 & 40,00 & 46,00 \\
\hline B53 & 58,00 & 60,00 & 56,00 & 58,00 \\
\hline B56 & 58,00 & 60,00 & 40,00 & 52,67 \\
\hline B57 & 58,00 & 52,00 & 44,00 & 51,33 \\
\hline B59 & 58,00 & 48,00 & 20,00 & 42,00 \\
\hline B61 & 58,00 & 56,00 & 40,00 & 51,33 \\
\hline B64 & 58,00 & 64,00 & 44,00 & 55,33 \\
\hline B65 & 58,00 & 56,00 & 40,00 & 51,33 \\
\hline B67 & 54,00 & 56,00 & 40,00 & 50,00 \\
\hline B73 & 58,00 & 60,00 & 52,00 & 56,67 \\
\hline B74 & 58,00 & 60,00 & 48,00 & 55,33 \\
\hline B76 & 62,00 & 64,00 & 56,00 & 60,67 \\
\hline B77 & 58,00 & 64,00 & 48,00 & 56,67 \\
\hline B81 & 62,00 & 64,00 & 60,00 & 62,00 \\
\hline B82 & 58,00 & 60,00 & 44,00 & 54,00 \\
\hline B83 & 58,00 & 60,00 & 52,00 & 56,67 \\
\hline B84 & 54,00 & 56,00 & 28,00 & 46,00 \\
\hline B85 & 58,00 & 64,00 & 52,00 & 58,00 \\
\hline B86 & 58,00 & 60,00 & 40,00 & 52,67 \\
\hline B87 & 54,00 & 64,00 & 56,00 & 58,00 \\
\hline B88 & 38,00 & 56,00 & 40,00 & 44,67 \\
\hline B89 & 58,00 & 56,00 & 40,00 & 51,33 \\
\hline B90 & 58,00 & 60,00 & 52,00 & 56,67 \\
\hline B91 & 58,00 & 64,00 & 60,00 & 60,67 \\
\hline B92 & 54,00 & 60,00 & 24,00 & 46,00 \\
\hline B94 & 54,00 & 60,00 & 56,00 & 56,67 \\
\hline B97 & 58,00 & 40,00 & 40,00 & 46,00 \\
\hline B99 & 58,00 & 64,00 & 55,00 & 59,00 \\
\hline B101 & 58,00 & 60,00 & 60,00 & 59,33 \\
\hline B102 & 54,00 & 60,00 & 54,00 & 56,00 \\
\hline B103 & 58,00 & 64,00 & 58,00 & 60,00 \\
\hline
\end{tabular}


APÊNDICE 5 - Valores do índice de emulsificação $\left(\mathbb{E}_{24}\right)$ para os cultivos dos 161 isolados em meio mineral tendo como fonte de carbono $2 \%$ de etanol. Os valores representam 3 repetições para cada isolado.

\begin{tabular}{|c|c|c|c|c|}
\hline ISOLADOS & Exp.1 (\%) & Exp. 2 (\%) & Exp. 3 (\%) & Média \\
\hline A. calcoacelicus RAG1 & 40,00 & 40,00 & 48,00 & 42,67 \\
\hline B. licheniformis & 60,00 & 60,00 & 60,00 & 60,00 \\
\hline B. subtilis & 48,00 & 48,00 & 50,00 & 48,67 \\
\hline B105 & 56,00 & 40,00 & 40,00 & 45,33 \\
\hline B106 & 56,00 & 60,00 & 60,00 & 58,67 \\
\hline B107 & 63,00 & 60,00 & 60,00 & 61,00 \\
\hline B108 & 56,00 & 68,00 & 54,00 & 59,33 \\
\hline B109 & 59,00 & 64,00 & 60,00 & 61,00 \\
\hline B110 & 63,00 & 52,00 & 52,00 & 55,67 \\
\hline B111 & 63,00 & 28,00 & 50,00 & 47,00 \\
\hline B112 & 63,00 & 52,00 & 52,00 & 55,67 \\
\hline B113 & 63,00 & 60,00 & 60,00 & 61,00 \\
\hline B114 & 56,00 & 68,00 & 56,00 & 60,00 \\
\hline B115 & 56,00 & 68,00 & 50,00 & 58,00 \\
\hline B116 & 19,00 & 28,00 & 50,00 & 32,33 \\
\hline B117 & 56,00 & 60,00 & 60,00 & 58,67 \\
\hline B118 & 56,00 & 40,00 & 50,00 & 48,67 \\
\hline B119 & 63,00 & 44,00 & 50,00 & 52,33 \\
\hline B120 & 56,00 & 40,00 & 50,00 & 48,67 \\
\hline B121 & 63,00 & 60,00 & 58,00 & 60,33 \\
\hline B122 & 56,00 & 60,00 & 60,00 & 58,67 \\
\hline B123 & 56,00 & 56,00 & 56,00 & 56,00 \\
\hline B126 & 56,00 & 64,00 & 60,00 & 60,00 \\
\hline B128 & 59,00 & 60,00 & 60,00 & 59,67 \\
\hline B130 & 56,00 & 64,00 & 60,00 & 60,00 \\
\hline B131 & 37,00 & 64,00 & 60,00 & 53,67 \\
\hline B132 & 37,00 & 68,00 & 50,00 & 51,67 \\
\hline B133 & 59,00 & 60,00 & 48,00 & 55,67 \\
\hline B134 & 63,00 & 60,00 & 60,00 & 61,00 \\
\hline & & & & \\
\hline
\end{tabular}


APÊNDICE 6 - Valores do índice de emulsificação $\left(\mathrm{IE}_{24}\right)$ para os cultivos dos 161 isolados em meio mineral tendo como fonte de carbono $2 \%$ de etanol. Os valores representam 3 repetições para cada isolado.

\begin{tabular}{|c|c|c|c|c|}
\hline ISOLADOS & Exp.1 (\%) & Exp. 2 (\%) & Exp. 3 (\%) & Média \\
\hline A. calcoaceticus RAG1 & 54,40 & 56,00 & 60,00 & 56,80 \\
\hline B. licheniformis & 51,40 & 48,00 & 50,00 & 49,80 \\
\hline B. subtilis & 47,40 & 48,00 & 48,00 & 47,80 \\
\hline B135 & 56,00 & 56,00 & 50,00 & 54,00 \\
\hline B138 & 37,00 & 60,00 & 40,00 & 45,67 \\
\hline B139 & 56,00 & 60,00 & 50,00 & 55,33 \\
\hline B140 & 37,00 & 64,00 & 50,00 & 50,33 \\
\hline B141 & 56,00 & 60,00 & 50,00 & 55,33 \\
\hline B142 & 56,00 & 60,00 & 50,00 & 55,33 \\
\hline B143 & 56,00 & 60,00 & 50,00 & 55,33 \\
\hline B145 & 56,00 & 32,00 & 50,00 & 46,00 \\
\hline B146 & 56,00 & 60,00 & 60,00 & 58,67 \\
\hline B147 & 56,00 & 60,00 & 60,00 & 58,67 \\
\hline B148 & 56,00 & 60,00 & 56,00 & 57,33 \\
\hline B149 & 56,00 & 32,00 & 50,00 & 46,00 \\
\hline B150 & 56,00 & 40,00 & 50,00 & 48,67 \\
\hline B151 & 59,00 & 60,00 & 50,00 & 56,33 \\
\hline B152 & 59,00 & 64,00 & 58,00 & 60,33 \\
\hline B153 & 59,00 & 64,00 & 60,00 & 61,00 \\
\hline B155 & 56,00 & 60,00 & 60,00 & 58,67 \\
\hline B156 & 59,00 & 64,00 & 60,00 & 61,00 \\
\hline B157 & 59,00 & 64,00 & 60,00 & 61,00 \\
\hline B158 & 56,00 & 64,00 & 60,00 & 60,00 \\
\hline B159 & 56,00 & 60,00 & 60,00 & 58,67 \\
\hline B160 & 56,00 & 60,00 & 50,00 & 55,33 \\
\hline B161 & 48,00 & 60,00 & 50,00 & 52,67 \\
\hline B162 & 56,00 & 32,00 & 50,00 & 46,00 \\
\hline B163 & 56,00 & 60,00 & 50,00 & 55,33 \\
\hline B164 & 52,00 & 60,00 & 56,00 & 56,00 \\
\hline & 48,00 & 32,00 & 50,00 & 43,33 \\
\hline & & & & \\
\hline
\end{tabular}


APÊNDICE 7 - Valores do índice de emulsificação $\left(\mathbb{I E}_{24}\right)$ para os cultivos dos 161 isolados em meio mineral tendo como fonte de carbono $2 \%$ de etanol.

Os valores representam 3 repetições para cada isolado.

\begin{tabular}{|c|c|c|c|c|}
\hline ISOLADOS & Exp.1 (\%) & Exp. 2 (\%) & Exp. 3 (\%) & Média \\
\hline B165 & 37,00 & 60,00 & 50,00 & 49,00 \\
\hline B166 & 68,00 & 64,00 & 60,00 & 64,00 \\
\hline B167 & 60,00 & 60,00 & 60,00 & 60,00 \\
\hline B168 & 60,00 & 64,00 & 60,00 & 61,33 \\
\hline B169 & 52,00 & 60,00 & 50,00 & 54,00 \\
\hline B170 & 60,00 & 60,00 & 58,00 & 59,33 \\
\hline B171 & 60,00 & 60,00 & 58,00 & 59,33 \\
\hline B172 & 64,00 & 60,00 & 60,00 & 61,33 \\
\hline B173 & 56,00 & 56,00 & 50,00 & 54,00 \\
\hline B174 & 50,00 & 56,00 & 54,00 & 61,00 \\
\hline B175 & 52,00 & 60,00 & 54,00 & 55,33 \\
\hline B176 & 50,00 & 64,00 & 47,00 & 53,67 \\
\hline B177 & 60,00 & 56,00 & 53,00 & 56,33 \\
\hline B178 & 68,00 & 52,00 & 58,00 & 59,33 \\
\hline B179 & 64,00 & 60,00 & 54,00 & 59,33 \\
\hline B180 & 60,00 & 60,00 & 60,00 & 60,00 \\
\hline B181 & 64,00 & 64,00 & 60,00 & 62,67 \\
\hline B182 & 56,00 & 32,00 & 58,00 & 48,67 \\
\hline B183 & 64,00 & 60,00 & 58,00 & 60,67 \\
\hline B184 & 60,00 & 64,00 & 60,00 & 61,33 \\
\hline B185 & 52,00 & 60,00 & 54,00 & 55,33 \\
\hline B186 & 64,00 & 60,00 & 53,00 & 59,00 \\
\hline B187 & 60,00 & 52,00 & 58,00 & 56,67 \\
\hline B189 & 52,00 & 60,00 & 58,00 & 56,67 \\
\hline B190 & 60,00 & 56,00 & 60,00 & 58,67 \\
\hline B191 & 56,00 & 52,00 & 54,00 & 54,00 \\
\hline B192 & 64,00 & 52,00 & 56,00 & 57,33 \\
\hline B193 & 48,00 & 68,00 & 60,00 & 58,67 \\
\hline B194 & 48,00 & 60,00 & 50,00 & 52,67 \\
\hline B195 & 56,00 & 60,00 & 58,00 & 58,00 \\
\hline B196 & 60,00 & 60,00 & 60,00 & 60,00 \\
\hline & 52,00 & 60,00 & 60,00 & 57,33 \\
\hline
\end{tabular}


APÊNDICE 8 - Valores de atividade emulsificante $\left(\mathrm{U} \mathrm{mL}^{-1}\right)$ para os cultivos dos 161 isolados em meio mineral tendo como fonte de carbono $2 \%$ de etanol. Os valores representam 3 repetições para cada isolado.

\begin{tabular}{|c|c|c|c|c|}
\hline ISOLADOS & Exp. 1 & Exp. 2 & Exp. 3 & Média \\
\hline A. calcoaceticus RAG1 & 10,80 & 10,50 & 13,50 & 11,60 \\
\hline B. licheniformis & 4,50 & 3,00 & 7,50 & 5,00 \\
\hline B. subtilis & 9,75 & 12,75 & 15,00 & 12,50 \\
\hline B03 & 22,50 & 36,00 & 4,50 & 21,00 \\
\hline B05 & 12,75 & 11,10 & 20,25 & 14,70 \\
\hline B07 & 6,15 & 11,25 & 1,05 & 6,15 \\
\hline B08 & 3,45 & 5,55 & 1,20 & 3,40 \\
\hline B09 & 4,05 & 5,25 & 1,20 & 3,50 \\
\hline B10 & 21,00 & 27,45 & 10,50 & 19,65 \\
\hline B11 & 13,35 & 18,60 & 1,50 & 11,15 \\
\hline B13 & 28,05 & 37,50 & 12,60 & 26,05 \\
\hline B15 & 0,75 & 0,75 & 1,20 & 0,90 \\
\hline B16 & 21,75 & 24,00 & 1,05 & 15,60 \\
\hline B17 & 18,45 & 24,00 & 21,75 & 21,40 \\
\hline B18 & 2,25 & 3,00 & 1,05 & 2,10 \\
\hline B20 & 32,10 & 52,50 & 1,65 & 28,75 \\
\hline B21 & 36,75 & 56,25 & 28,50 & 40,50 \\
\hline B22 & 0,90 & 0,75 & 1,05 & 0,90 \\
\hline B23 & 21,75 & 23,70 & 1,95 & 15,80 \\
\hline B24 & 21,75 & 19,50 & 1,80 & 14,35 \\
\hline & 18,45 & 23,55 & 9,75 & 17,25 \\
\hline & & & & \\
\hline
\end{tabular}


APÊNDICE 9 - Valores atividade emulsificante $\left(\mathrm{U} \mathrm{mL}^{-1}\right)$ para os cultivos dos 161 isolados em meio mineral tendo como fonte de carbono $2 \%$ de etanol. Os valores representam 3 repetições para cada isolado.

\begin{tabular}{|c|c|c|c|c|}
\hline ISOLADOS & Exp. 1 & Exp. 2 & Exp. 3 & Média \\
\hline A. calcoaceticus RAGl & 24,60 & 22,80 & 19,70 & 22,37 \\
\hline B. licheniformis & 16,50 & 11,45 & 10,50 & 12,82 \\
\hline B. subtilis & 15,45 & 12,75 & 10,50 & 12,90 \\
\hline B52 & 24,00 & 22,50 & 22,50 & 23,00 \\
\hline B53 & 49,50 & 18,00 & 30,00 & 32,50 \\
\hline B56 & 36,30 & 31,50 & 28,50 & 32,10 \\
\hline B57 & 15,30 & 13,05 & 9,00 & 12,45 \\
\hline B59 & 52,50 & 37,50 & 10,50 & 33,50 \\
\hline B61 & 41,10 & 38,10 & 48,00 & 42,40 \\
\hline B64 & 30,90 & 31,50 & 34,50 & 32,30 \\
\hline B65 & 39,00 & 29,10 & 5,25 & 24,45 \\
\hline B67 & 36,30 & 31,50 & 16,50 & 28,10 \\
\hline B73 & 27,00 & 27,00 & 26,70 & 26,90 \\
\hline B74 & 37,50 & 31,50 & 8,40 & 25,80 \\
\hline B76 & 56,25 & 41,70 & 16,50 & 38,15 \\
\hline B77 & 42,00 & 30,00 & 24,00 & 32,00 \\
\hline B81 & 21,75 & 18,00 & 8,55 & 16,10 \\
\hline B82 & 9,75 & 18,45 & 28,50 & 18,90 \\
\hline B83 & 11,55 & 9,90 & 8,25 & 9,90 \\
\hline B84 & 32,10 & 40,05 & 18,30 & 30,15 \\
\hline B85 & 7,80 & 36,90 & 56,25 & 33,65 \\
\hline B86 & 14,10 & 9,75 & 2,25 & 8,70 \\
\hline B87 & 9,75 & 21,30 & 27,30 & 19,45 \\
\hline B88 & 3,45 & 5,25 & 8,25 & 5,65 \\
\hline B89 & 25,20 & 18,60 & 8,25 & 17,35 \\
\hline B90 & 5,40 & 3,90 & 1,95 & 3,75 \\
\hline B91 & 15,30 & 9,15 & 3,00 & 9,15 \\
\hline B92 & 24,75 & 14,10 & 10,50 & 16,45 \\
\hline B94 & 43,50 & 29,10 & 15,00 & 29,20 \\
\hline B97 & 45,00 & 42,75 & 45,00 & 44,25 \\
\hline B99 & 30,30 & 39,75 & 31,50 & 33,85 \\
\hline B101 & 20,85 & 14,85 & 12,00 & 15,90 \\
\hline B102 & 38,40 & 31,50 & 33,00 & 34,30 \\
\hline B103 & 36,00 & 22,80 & 19,50 & 26,10 \\
\hline
\end{tabular}


APÊNDICE 10 - Valores de atividade emulsificante $\left(\mathrm{U} \mathrm{mL}^{-1}\right)$ para os cultivos dos 161 isolados em meio mineral tendo como fonte de carbono $2 \%$ de etanol. Os valores representam 3 repetições para cada isolado.

\begin{tabular}{|c|c|c|c|c|}
\hline ISOLADOS & Exp. 1 & Exp. 2 & Exp. 3 & Média \\
\hline A. calcoaceticus RAG1 & 24,60 & 22,80 & 19,70 & 22,37 \\
\hline B. licheniformis & 16,50 & 11,45 & 10,50 & 12,82 \\
\hline B. subtilis & 15,45 & 12,75 & 10,50 & 12,90 \\
\hline B52 & 24,00 & 22,50 & 22,50 & 23,00 \\
\hline B53 & 49,50 & 18,00 & 30,00 & 32,50 \\
\hline B56 & 36,30 & 31,50 & 28,50 & 32,10 \\
\hline B57 & 15,30 & 13,05 & 9,00 & 12,45 \\
\hline B59 & 52,50 & 37,50 & 10,50 & 33,50 \\
\hline B61 & 41,10 & 38,10 & 48,00 & 42,40 \\
\hline B64 & 30,90 & 31,50 & 34,50 & 32,30 \\
\hline B65 & 39,00 & 29,10 & 5,25 & 24,45 \\
\hline B67 & 36,30 & 31,50 & 16,50 & 28,10 \\
\hline B73 & 27,00 & 27,00 & 26,70 & 26,90 \\
\hline B74 & 37,50 & 31,50 & 8,40 & 25,80 \\
\hline B76 & 56,25 & 41,70 & 16,50 & 38,15 \\
\hline B77 & 42,00 & 30,00 & 24,00 & 32,00 \\
\hline B81 & 21,75 & 18,00 & 8,55 & 16,10 \\
\hline B82 & 9,75 & 18,45 & 28,50 & 18,90 \\
\hline B83 & 11,55 & 9,90 & 8,25 & 9,90 \\
\hline B84 & 32,10 & 40,05 & 18,30 & 30,15 \\
\hline B85 & 7,80 & 36,90 & 56,25 & 33,65 \\
\hline B86 & 14,10 & 9,75 & 2,25 & 8,70 \\
\hline B87 & 9,75 & 21,30 & 27,30 & 19,45 \\
\hline B88 & 3,45 & 5,25 & 8,25 & 5,65 \\
\hline B89 & 25,20 & 18,60 & 8,25 & 17,35 \\
\hline B90 & 5,40 & 3,90 & 1,95 & 3,75 \\
\hline B91 & 15,30 & 9,15 & 3,00 & 9,15 \\
\hline B92 & 24,75 & 14,10 & 10,50 & 16,45 \\
\hline B94 & 43,50 & 29,10 & 15,00 & 29,20 \\
\hline B97 & 45,00 & 42,75 & 45,00 & 44,25 \\
\hline B99 & 30,30 & 39,75 & 31,50 & 33,85 \\
\hline B101 & 20,85 & 14,85 & 12,00 & 15,90 \\
\hline B102 & 38,40 & 31,50 & 33,00 & 34,30 \\
\hline B103 & 36,00 & 22,80 & 19,50 & 26,10 \\
\hline
\end{tabular}


APÊNDICE 11 - Valores de atividade emulsificante $\left(\mathrm{U} \mathrm{mL}^{-1}\right)$ para os cultivos dos 161 isolados em meio mineral tendo como fonte de carbono $2 \%$ de etanol. Os valores representam 3 repetições para cada isolado.

\begin{tabular}{|c|c|c|c|c|}
\hline ISOLADOS & Exp. 1 & Exp. 2 & Exp. 3 & Média \\
\hline A. calcoaceticus RAG1 & 17,87 & 14,96 & 23,95 & 18,93 \\
\hline B. licheniformis & 19,65 & 13,70 & 10,30 & 14,55 \\
\hline B. subtilis & 21,15 & 15,00 & 12,50 & 16,22 \\
\hline B105 & 8,40 & 7,65 & 7,20 & 7,75 \\
\hline B106 & 31,50 & 18,45 & 6,00 & 18,65 \\
\hline B107 & 38,10 & 37,50 & 36,00 & 37,20 \\
\hline B108 & 3,90 & 4,95 & 6,00 & 4,95 \\
\hline B109 & 4,20 & 14,25 & 27,00 & 15,15 \\
\hline B110 & 8,55 & 14,70 & 18,45 & 13,90 \\
\hline B111 & 33,90 & 22,80 & 14,25 & 23,65 \\
\hline B113 & 17,55 & 15,90 & 14,25 & 15,90 \\
\hline B114 & 9,00 & 14,10 & 21,75 & 14,95 \\
\hline B115 & 21,00 & 19,50 & 25,50 & 22,00 \\
\hline B116 & 20,55 & 18,00 & 13,95 & 17,50 \\
\hline B117 & 39,30 & 18,00 & 28,50 & 28,60 \\
\hline B118 & 21,45 & 24,60 & 38,10 & 28,05 \\
\hline B119 & 25,50 & 37,65 & 48,00 & 37,05 \\
\hline B120 & 54,00 & 33,45 & 45,00 & 44,15 \\
\hline B121 & 42,60 & 37,65 & 37,50 & 39,25 \\
\hline B122 & 15,30 & 13,80 & 8,70 & 12,60 \\
\hline B123 & 35,10 & 31,50 & 35,40 & 34,00 \\
\hline B126 & 18,60 & 24,60 & 31,50 & 24,90 \\
\hline B128 & 11,70 & 19,35 & 23,85 & 18,30 \\
\hline B129 & 7,20 & 7,50 & 7,95 & 7,55 \\
\hline B130 & 4,50 & 10,50 & 12,45 & 9,15 \\
\hline B131 & 21,00 & 5,25 & 8,40 & 11,55 \\
\hline B133 & 16,50 & 1,80 & 12,00 & 10,10 \\
\hline B134 & 4,20 & 2,10 & 7,50 & 4,60 \\
\hline & 29,25 & 2,70 & 5,55 & 12,50 \\
\hline & 8,85 & 12,00 & 2,55 & 7,80 \\
\hline & & & \\
\hline
\end{tabular}


APÊNDICE 12 - Valores de atividade emulsificante $\left(\mathrm{U} \mathrm{mL}^{-1}\right)$ para os cultivos dos 161 isolados em meio mineral tendo como fonte de carbono $2 \%$ de etanol. Os valores representam 3 repetições para cada isolado.

\begin{tabular}{|c|c|c|c|c|}
\hline ISOLADOS & Exp. 1 & Exp. 2 & Exp. 3 & Média \\
\hline A. calcoaceticus RAGl & 9,50 & 10,70 & 22,80 & 14,33 \\
\hline B. licheniformis & 13,05 & 16,50 & 7,35 & 12,30 \\
\hline B. subtilis & 24,60 & 21,50 & 7,35 & 17,82 \\
\hline B135 & 21,75 & 2,25 & 22,20 & 15,40 \\
\hline B138 & 1,05 & 1,50 & 1,35 & 1,30 \\
\hline B139 & 4,65 & 3,60 & 6,00 & 4,75 \\
\hline B140 & 8,10 & 6,90 & 13,50 & 9,50 \\
\hline B141 & 18,60 & 25,50 & 16,50 & 20,20 \\
\hline B142 & 18,15 & 9,90 & 19,20 & 15,75 \\
\hline B143 & 10,05 & 1,05 & 13,20 & 8,10 \\
\hline B144 & 14,70 & 1,65 & 16,50 & 10,95 \\
\hline B 145 & 21,75 & 15,30 & 27,00 & 21,35 \\
\hline B146 & 12,60 & 1,05 & 22,05 & 11,90 \\
\hline B147 & 16,65 & 6,60 & 18,90 & 14,05 \\
\hline B148 & 15,30 & 17,40 & 20,40 & 17,70 \\
\hline B149 & 19,50 & 18,60 & 16,50 & 18,20 \\
\hline B150 & 4,05 & 3,00 & 8,25 & 5,10 \\
\hline B151 & 18,45 & 14,55 & 24,00 & 19,00 \\
\hline B152 & 6,75 & 3,30 & 8,25 & 6,10 \\
\hline B153 & 18,90 & 12,00 & 21,75 & 17,55 \\
\hline B155 & 8,85 & 2,25 & 18,00 & 9,70 \\
\hline B156 & 7,65 & 9,15 & 10,50 & 9,10 \\
\hline B157 & 8,10 & 1,65 & 13,65 & 7,80 \\
\hline B158 & 29,55 & 3,30 & 37,50 & 23,45 \\
\hline B159 & 15,00 & 18,30 & 22,50 & 18,60 \\
\hline B160 & 6,75 & 1,50 & 8,10 & 5,45 \\
\hline B161 & 18,90 & 24,00 & 23,40 & 22,10 \\
\hline B162 & 7,20 & 1,65 & 5,10 & 4,65 \\
\hline B163 & 18,00 & 21,45 & 15,00 & 18,15 \\
\hline B164 & 14,10 & 11,55 & 12,60 & 12,75 \\
\hline B165 & 18,00 & 19,80 & 17,25 & 18,35 \\
\hline
\end{tabular}


APÊNDICE 13 - Valores de atividade emulsificante $\left(\mathrm{U} \mathrm{mL}^{-1}\right)$ para os cultivos dos 161 isolados em meio mineral tendo como fonte de carbono $2 \%$ de etanol. Os valores representam 3 repetições para cada isolado.

\begin{tabular}{|c|c|c|c|c|}
\hline ISOLADOS & Exp. 1 (\%) & Exp. 2 (\%) & Exp. 3 (\%) & Média \\
\hline B166 & 11,55 & 2,70 & 9,75 & 8,00 \\
\hline B167 & 13,50 & 5,40 & 5,10 & 8,00 \\
\hline B168 & 5,85 & 9,75 & 11,10 & 8,90 \\
\hline B169 & 16,50 & 25,50 & 19,50 & 20,50 \\
\hline B170 & 6,45 & 11,25 & 8,10 & 8,60 \\
\hline B171 & 3,75 & 5,25 & 1,50 & 3,50 \\
\hline B173 & 13,50 & 2,40 & 6,75 & 7,55 \\
\hline B174 & 50,25 & 38,70 & 38,10 & 42,35 \\
\hline B175 & 48,75 & 20,70 & 32,10 & 33,85 \\
\hline B176 & 11,10 & 7,95 & 3,75 & 7,60 \\
\hline B177 & 6,75 & 1,50 & 5,10 & 4,45 \\
\hline B178 & 9,45 & 8,25 & 3,15 & 6,95 \\
\hline B179 & 5,25 & 1,50 & 3,00 & 3,25 \\
\hline B180 & 12,00 & 24,90 & 23,40 & 20,10 \\
\hline B181 & 39,30 & 1,80 & 29,55 & 23,55 \\
\hline B182 & 24,00 & 3,30 & 22,80 & 16,70 \\
\hline B183 & 3,00 & 2,25 & 4,80 & 3,35 \\
\hline B184 & 7,05 & 1,80 & 3,60 & 4,15 \\
\hline B185 & 3,90 & 1,50 & 5,10 & 3,50 \\
\hline B186 & 5,40 & 8,10 & 6,30 & 6,60 \\
\hline B187 & 17,40 & 1,20 & 6,75 & 8,45 \\
\hline B188 & 10,65 & 1,35 & 8,55 & 6,85 \\
\hline B189 & 22,05 & 15,00 & 18,75 & 18,60 \\
\hline B190 & 9,00 & 34,50 & 27,75 & 23,75 \\
\hline B191 & 8,40 & 4,50 & 1,50 & 4,80 \\
\hline B192 & 48,75 & 1,65 & 18,00 & 22,80 \\
\hline B193 & 11,25 & 27,00 & 12,60 & 16,95 \\
\hline B194 & 11,25 & 10,05 & 8,10 & 9,80 \\
\hline B195 & 12,75 & 1,80 & 6,45 & 7,00 \\
\hline & 8,25 & 9,75 & 8,10 & 8,70 \\
\hline & 3,00 & 1,50 & 5,10 & 3,20 \\
\hline
\end{tabular}


APÊNDICE 14 - Análise de variância para atividade emulsificante dos cultivos dos 161 isolados.

\begin{tabular}{|c|c|c|c|c|c|c|c|}
\hline \multicolumn{3}{|c|}{ Source of variation } & $\begin{array}{l}\text { Sum of } \\
\text { Squares }\end{array}$ & d.f. & $\begin{array}{l}\text { Mean } \\
\text { square }\end{array}$ & F-ratio & $\begin{array}{l}\text { Sig. } \\
\text { level }\end{array}$ \\
\hline \multicolumn{3}{|c|}{ A:PUPINAE3.TRATAMENT } & $\overline{9357.83} 62$ & 22 & 425.35619 & 4.614 & .0000 \\
\hline \multicolumn{3}{|l|}{ RESIDUAL } & 4240.8350 & 46 & 92.192065 & & \\
\hline \multicolumn{3}{|c|}{ TOTAL (CORRECTED) } & 13598.671 & \multicolumn{2}{|l|}{68} & & \\
\hline \multicolumn{8}{|c|}{ Method: $\quad 95$ Percent Tukey } \\
\hline Level $\quad \mathrm{Cc}$ & Count & LS Mean & \multicolumn{3}{|c|}{ Homogeneous Groups } & & \\
\hline 178 & 3 & 3.250000 & $\mathrm{X}$ & & & & \\
\hline 171 & 3 & 3.500000 & $\mathrm{X}$ & & & & \\
\hline 160 & 3 & 5.450000 & $X X$ & & & & \\
\hline 166 & 3 & 8.000000 & $\mathrm{XXX}$ & & & & \\
\hline 167 & 3 & 8.000000 & $\mathrm{XXX}$ & & & & \\
\hline 170 & 3 & 8.600000 & $\mathrm{XXX}$ & & & & \\
\hline 168 & 3 & 8.900000 & XXX & & & & \\
\hline B. licheniformis & & 11.300000 & $\mathrm{XXXX}$ & & & & \\
\hline B. subtilis & 3 & 14.440000 & XXXXX & & & & \\
\hline A. calcoaceticus & & 18.680000 & $\mathrm{XXXXX}$ & & & & \\
\hline 151 & 3 & 19.000000 & $\mathrm{XXXX}$ & & & & \\
\hline 179 & 3 & 20.100000 & $\mathrm{XXXXX}$ & & & & \\
\hline 145 & 3 & 21.350000 & XXXXX & & & & \\
\hline 191 & 3 & 22.800000 & $X X X X X$ & & & & \\
\hline 158 & 3 & 23.450000 & XXXXX & & & & \\
\hline 180 & 3 & 23.550000 & XXXXX & & & & \\
\hline 189 & 3 & 23.750000 & XXXXX & & & & \\
\hline 123 & 3 & 24.900000 & XXXXX & & & & \\
\hline 174 & 3 & 33.850000 & $\mathrm{XXXX}$ & & & & \\
\hline 122 & 3 & 34.000000 & $\mathrm{XXXX}$ & & & & \\
\hline 118 & 3 & 37.050000 & $X X X$ & & & & \\
\hline 120 & 3 & 39.250000 & $X X$ & & & & \\
\hline 119 & 3 & 44.150000 & $\mathrm{X}$ & & & & \\
\hline
\end{tabular}


APÊNDICE 15 - Análise de variância para o índice de emulsificação, dos cultivos dos 161 isolados.

\begin{tabular}{llllll}
\hline Source of variation & $\begin{array}{l}\text { sum of } \\
\text { squares }\end{array}$ & d.f. & $\begin{array}{l}\text { Mean } \\
\text { square }\end{array}$ & F-ratio & $\begin{array}{l}\text { Sig. } \\
\text { Level }\end{array}$ \\
\hline A:PUPINIE2.TRATAMENT & 565.18133 & 15 & 37.678756 & 3.297 & .0022 \\
RESIDUAL & 365.66427 & 32 & 11.427008 & & \\
TOTAL (CORRECTED) & 930.84560 & 47 & & & \\
\hline
\end{tabular}

Method: 95 Percent Tukey

Level Count LS Mean Homogeneous Groups .

$\begin{array}{llll}\text { B. subtilis } & 3 & 48.960000 & \mathrm{X} \\ \text { B. licheniformis } & 3 & 51.200000 & \mathrm{XX} \\ \text { A. calcoaceticus } & 3 & 55.500000 & \mathrm{XX} \\ 133 & 3 & 55.733333 & \mathrm{XX} \\ 150 & 3 & 56.400000 & \mathrm{XX} \\ 147 & 3 & 57.166667 & \mathrm{XX} \\ 145 & 3 & 58.500000 & \mathrm{XX} \\ 146 & 3 & 58.500000 & \mathrm{XX} \\ 153 & 3 & 58.500000 & \mathrm{XX} \\ 158 & 3 & 58.500000 & \mathrm{XX} \\ 157 & 3 & 59.833333 & \mathrm{X} \\ 151 & 3 & 60.400000 & \mathrm{X} \\ 134 & 3 & 60.966667 & \mathrm{X} \\ 152 & 3 & 61.066667 & \mathrm{X} \\ 155 & 3 & 61.066667 & \mathrm{X} \\ 156 & 3 & 61.066667 & \mathrm{X}\end{array}$




\begin{tabular}{|c|c|c|}
\hline Contrast & Diference & Limits \\
\hline $\begin{array}{l}\text { A. calcoaceticus RAG1 - B. } \\
\text { licheniformis }\end{array}$ & 4.30000 & 10.2355 \\
\hline $\begin{array}{l}\text { A. calcoaceticus RAG1 - B. } \\
\text { subtilis }\end{array}$ & 6.54000 & 10.2355 \\
\hline $\begin{array}{l}\text { A. calcoaceticus RAG1 - } \\
\text { B133 }\end{array}$ & -0.23333 & 10.2355 \\
\hline $\begin{array}{l}\text { A. calcoaceticus RAG1 - } \\
\text { B134 }\end{array}$ & -5.46667 & 10.2355 \\
\hline $\begin{array}{l}\text { A. calcoaceticus RAG1 - } \\
\text { B } 145\end{array}$ & -3.00000 & 10.2355 \\
\hline $\begin{array}{l}\text { A. calcoaceticus RAG1 - } \\
\text { B146 }\end{array}$ & -3.00000 & 10.2355 \\
\hline $\begin{array}{l}\text { A. calcoaceticus RAG1 - } \\
\text { B147 }\end{array}$ & -1.66667 & 10.2355 \\
\hline $\begin{array}{l}\text { A. calcoaceticus RAG1 - } \\
\text { B150 }\end{array}$ & -0.90000 & 10.2355 \\
\hline $\begin{array}{l}\text { A. calcoaceticus RAG1 - } \\
\text { B151 }\end{array}$ & -4.90000 & 10.2355 \\
\hline $\begin{array}{l}\text { A. calcoaceticus RAG1 - } \\
\text { B152 }\end{array}$ & -5.56667 & 10.2355 \\
\hline $\begin{array}{l}\text { A. calcoaceticus RAG1 - } \\
\text { B153 }\end{array}$ & -3.00000 & 10.2355 \\
\hline $\begin{array}{l}\text { A. calcoaceticus RAG1 - } \\
\text { B155 }\end{array}$ & -5.56667 & 10.2355 \\
\hline $\begin{array}{l}\text { A. calcoaceticus RAG1 - } \\
\text { B156 }\end{array}$ & -5.56667 & 10.2355 \\
\hline $\begin{array}{l}\text { A. calcoaceticus RAG1 - } \\
\text { B157 }\end{array}$ & -4.33333 & 10.2355 \\
\hline $\begin{array}{l}\text { A. calcoaceticus RAG1 - } \\
\text { B158 }\end{array}$ & -3.00000 & 10.2355 \\
\hline B. licheniformis - B. subtilis & 2.24000 & 10.2355 \\
\hline B. licheniformis - B133 & -4.53333 & 10.2355 \\
\hline B. licheniformis - B134 & -9.76667 & 10.2355 \\
\hline B. licheniformis - В 145 & -7.30000 & 10.2355 \\
\hline B. licheniformis - B146 & -7.30000 & 10.2355 \\
\hline B. licheniformis - B147 & -5.96667 & 10.2355 \\
\hline B. licheniformis - B 150 & -5.20000 & 10.2355 \\
\hline B. licheniformis - B151 & -9.20000 & 10.2355 \\
\hline B. licheniformis - B152 & -9.86667 & 10.2355 \\
\hline B. licheniformis - B 153 & -7.30000 & 10.2355 \\
\hline B. licheniformis - B 155 & -9.86667 & 10.2355 \\
\hline B. licheniformis - B156 & -9.86667 & 10.2355 \\
\hline B. licheniformis - B 157 & -8.63333 & 10.2355 \\
\hline B. licheniformis - B 158 & -7.30000 & 10.2355 \\
\hline
\end{tabular}


B. subtilis - B133

$-6.77333$

10.2355

B. subtilis - B134

$-12.0067$

$10.2355^{*}$

B. subtilis - B145

$-9.54000$

10.2355

B. subtilis-B146

$-9.54000$

10.2355

B. subtilis - B147

$-8.20667$

10.2355

B. subtilis - B150

$-7.44000$

10.2355

B. subtilis - B151

$-11.4400$

$10.2355^{*}$

B. subtilis - B152

$-12.1067$

$10.2355^{*}$

B. subtilis - B153

$-9.54000$

10.2355

B. subtilis - B155

$-12.1067$

B. subtilis - B156

$-12.1067$

$10.2355^{*}$

B. subtilis - B 157

B. subtilis - B158

$-10.8733$

$-9.54000$

$10.2355^{*}$

$10.2355^{*}$

10.2355

B133 - B134

B133 - B145

$-5.23333$

10.2355

$-2.76667$

10.2355

B133 - B146

$-2.76667$

10.2355

B133 - B147

$-1.43333$

10.2355

B133 - B150

$-0,66667$

10.2355

B133 - B 151

B133 - B152

$-4.66667$

10.2355

$-5.33333$

10.2355

B133 - B153

$-2.76667$

10.2355

B133 - B155

$-5.33333$

10.2355

B133 - B156

$-5.33333$

10.2355

B133 - B157

$-4.10000$

10.2355

$-2.76667$

10.2355

2.46667

10.2355

2.46667

10.2355

3.80000

10.2355

4.56667

10.2355

0.56667

10.2355

$-0.10000$

10.2355

2.46667

10.2355

$-0.10000$

10.2355

$-0.10000$

10.2355

1.13333

10.2355

2.46667

10.2355

0.00000

10.2355

1.33333

10.2355

2. 10000

10.2355

$-1.90000$

10.2355

$-2.56667$

10.2355

0.00000

10.2355

$-2.56667$

10.2355

$-2.56667$

10.2355

B145 - B156

$-1.33333$

10.2355 


$\begin{array}{lll}\mathrm{B} 145-\mathrm{B} 158 & 0.00000 & 10.2355 \\ \mathrm{~B} 146-\mathrm{B} 147 & 1.33333 & 10.2355 \\ \mathrm{~B} 146-\mathrm{B} 150 & 2.10000 & 10.2355 \\ \mathrm{~B} 146-\mathrm{B} 151 & -1.90000 & 10.2355 \\ \mathrm{~B} 146-\mathrm{B} 152 & -2.56667 & 10.2355 \\ \mathrm{~B} 146-\mathrm{B} 153 & 0.00000 & 10.2355 \\ \mathrm{~B} 146-\mathrm{B} 155 & -2.56667 & 10.2355 \\ \mathrm{~B} 146-\mathrm{B} 156 & -2.56667 & 10.2355 \\ \mathrm{~B} 146-\mathrm{B} 157 & -1.33333 & 10.2355 \\ \mathrm{~B} 146-\mathrm{B} 158 & 0.00000 & 10.2355 \\ \mathrm{~B} 147-\mathrm{B} 150 & 0.76667 & 10.2355 \\ \mathrm{~B} 147-\mathrm{B} 151 & -3.23333 & 10.2355 \\ \mathrm{~B} 147-\mathrm{B} 152 & -3.90000 & 10.2355 \\ \mathrm{~B} 147-\mathrm{B} 153 & -1.30000 & 10.2355 \\ \mathrm{~B} 147-\mathrm{B} 155 & -3.90000 & 10.2355 \\ \mathrm{~B} 147-\mathrm{B} 156 & -3.90000 & 10.2355 \\ \mathrm{~B} 147-\mathrm{B} 157 & -2.66667 & 10.2355 \\ \mathrm{~B} 147-\mathrm{B} 158 & -1.33333 & 10.2355 \\ \mathrm{~B} 150-\mathrm{B} 151 & -4.00000 & 10.2355 \\ \mathrm{~B} 150-\mathrm{B} 152 & -4.66667 & 10.2355 \\ \mathrm{~B} 150-\mathrm{B} 153 & -2.1000 & 10.2355 \\ \mathrm{~B} 150-\mathrm{B} 155 & -4.66667 & 10.2355 \\ \mathrm{~B} 150-\mathrm{B} 156 & -4.66667 & 10.2355 \\ \mathrm{~B} 150-\mathrm{B} 157 & -3.43333 & 10.2355 \\ \mathrm{~B} 150-\mathrm{B} 158 & -2.10000 & 10.2355 \\ \mathrm{~B} 151-\mathrm{B} 152 & -0.66667 & 10.2355 \\ \mathrm{~B} 151-\mathrm{B} 153 & 1.90000 & 10.2355 \\ \mathrm{~B} 151-\mathrm{B} 155 & -0.66667 & 10.2355 \\ \mathrm{~B} 151-\mathrm{B} 156 & -0.66667 & 10.2355 \\ \mathrm{~B} 151-\mathrm{B} 157 & 0.56667 & 10.2355 \\ \mathrm{~B} 151-\mathrm{B} 158 & 1.90000 & 10.2355 \\ \mathrm{~B} 152-\mathrm{B} 153 & 2.56667 & 10.2355 \\ \mathrm{~B} 152-\mathrm{B} 155 & 0.00000 & 10.2355 \\ \mathrm{~B} 152-\mathrm{B} 156 & 0.00000 & 10.2355 \\ \mathrm{~B} 152-\mathrm{B} 157 & 1.23333 & \\ \mathrm{~B} 152-\mathrm{B} 158 & 2.56667 & \end{array}$


APÊNDICE 16 - Cinética de crescimento dos isolados e dos microrganismos utilizados como padrões, crescidos em meio mineral com $2 \%$ de etanol. Leitura feita a cada 2 horas em espectrofotômetro Beckman a 580nm.

\begin{tabular}{|c|c|c|c|c|c|c|c|c|c|}
\hline Isolados & $\mathbf{0 h}$ & $2 \mathbf{h}$ & $4 \mathrm{~h}$ & $6 \mathrm{~h}$ & $8 \mathrm{~h}$ & $10 \mathrm{~h}$ & $12 \mathrm{~h}$ & $14 \mathrm{~h}$ & $24 \mathrm{~h}$ \\
\hline B118 & 0,0650 & 0,0710 & 0,0874 & 0,0947 & 0,1245 & 0,1532 & 0,1710 & 0,1870 & 0,4850 \\
\hline B119 & 0,0700 & 0,0818 & 0,0953 & 0,1143 & 0,1382 & 0,1609 & 0,1626 & 0,2145 & 0,5764 \\
\hline B120 & 0,0670 & 0,0745 & 0,0864 & 0,0947 & 0,1250 & 0,1590 & 0,1674 & 0,2170 & 0,5450 \\
\hline B122 & 0,0660 & 0,7410 & $0,0842 \mid$ & 0,0955 & 0,1370 & 0,1610 & 0,1745 & 0,1861 & 0,6740 \\
\hline B134 & 0,0740 & 0,0810 & $0,0947 \mid$ & 0,1200 & 0,1470 & 0,1740 & 0,1940 & 0,2200 & 0,5740 \\
\hline B151 & 0,0710 & 0,0812 & 0,0934 & 0,1740 & 0,1840 & 0,1890 & 0,2000 & 0,2240 & 0,5640 \\
\hline B152 & 0,0700 & 0,0817 & $0,0951 \mid$ & $|0,1100|$ & 0,1230 & 0,1450 & 0,1780 & 0,2160 & 0,5412 \\
\hline B155 & 0,0760 & 0,0831 & 0,0942 & 0,1000 & 0,1240 & 0,1460 & 0,1860 & 0,2140 & 0,5612 \\
\hline B156 & 0,0720 & 0,0846 & 0,0945 & $|0,1130|$ & 0,1250 & 0,1390 & 0,1790 & 0,1950 & 0,4540 \\
\hline B157 & 0,0730 & 0,0880 & 0,0934 & $|0,0987|$ & $|0,1260|$ & 0,1360 & 0,1710 & 0,1964 & 0,4645 \\
\hline B174 & 0,0710 & 0,0840 & 0,0870 & 0,0950 & 0,1340 & 0,1394 & 0,1570 & 0,1845 & 0,5874 \\
\hline $\begin{array}{c}\text { Acinetobacter calcoaceticus } \\
\text { RAG1 }\end{array}$ & 0,0700 & 0,0603 & 0,0600 & 0,0759 & 0,0950 & 0,0965 & 0,0980 & 0,1125 & 0,2900 \\
\hline Bacillus licheniformis & 0,0710 & 0,0670 & 0,0714 & 0,1042 & 0,1238 & 0,1368 & 0,1674 & 0,2375 & 0,6210 \\
\hline Bacillus subtilis & 0,0710 & 0,0760 & 0,0838 & 0,1139 & 0,1486 & 0,1549 & 0,1670 & 0,2183 & 0,6118 \\
\hline
\end{tabular}

\begin{tabular}{|c|c|c|c|c|c|c|c|c|}
\hline Isolados & $\mathbf{2 6 h}$ & $\mathbf{2 8 h}$ & $\mathbf{3 0 h}$ & $\mathbf{3 2 h}$ & $\mathbf{3 4 h}$ & $\mathbf{3 6 h}$ & $\mathbf{3 8 h}$ & $\mathbf{4 8 h}$ \\
\hline B118 & 0,5710 & 0,6230 & 0,7148 & 0,8164 & 0,9274 & 0,9870 & 1,0140 & \\
\hline B119 & 0,6696 & 0,7243 & 0,8056 & 0,8380 & 0,8566 & 0,9417 & 0,9887 & 1,0410 \\
\hline B120 & 0,6740 & 0,7420 & 0,8620 & 0,8940 & 0,9240 & 0,9957 & 1,1200 & \\
\hline B122 & 0,6970 & 0,7147 & 0,7890 & 0,8450 & 0,9220 & 0,9870 & 0,9910 & 1,0120 \\
\hline B134 & 0,6450 & 0,6870 & 0,7510 & 0,8000 & 0,8340 & 0,8930 & 0,9740 & 1,1400 \\
\hline B151 & 0,6510 & 0,6912 & 0,7450 & 0,7940 & 0,8270 & 0,8765 & 0,9571 & 1,0500 \\
\hline B152 & 0,6745 & 0,7000 & 0,7410 & 0,7840 & 0,8190 & 0,8840 & 0,9630 & 1,1000 \\
\hline B155 & 0,6454 & 0,6840 & 0,7200 & 0,8000 & 0,8420 & 0,9020 & 0,9780 & 1,1900 \\
\hline B156 & 0,5850 & 0,6200 & 0,6940 & 0,7540 & 0,8010 & 0,8820 & 0,9640 & 1,1060 \\
\hline B157 & 0,5445 & 0,6000 & 0,6860 & 0,7410 & 0,8000 & 0,8600 & 0,9540 & 1,1000 \\
\hline B174 & 0,6470 & 0,7240 & 0,8145 & 0,8974 & 0,9470 & 0,9870 & 0,9974 & 1,1120 \\
\hline RAG1 & 0,3487 & 0,4258 & 0,5126 & 0,5840 & 0,6260 & 0,8255 & 0,9046 & 1,1023 \\
\hline Acinetobacter calcoaceticus & & & & & & & & \\
\hline Bacillus licheniformis & 0,6837 & 0,7596 & 0,8323 & 0,8623 & 0,8778 & 0,9708 & 1,0306 & \\
\hline Bacillus subtilis & 0,7391 & 0,8326 & 0,9726 & 1,0520 & & & & \\
\hline
\end{tabular}




\begin{tabular}{|c|c|c|c|c|c|c|c|c|c|c|c|c|c|c|c|c|}
\hline \multirow{6}{*}{ 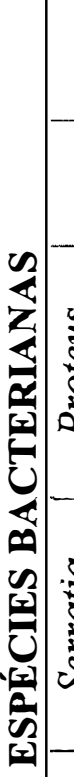 } & & 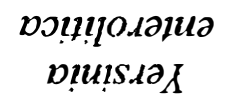 & $>$ & + & $>$ & ' & 1 & + & ' & 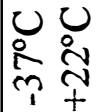 & 1 & ' & 1 & + & ' & ' \\
\hline & & 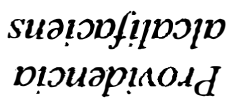 & + & + & 1 & + & 1 & ' & + & + & 1 & ' & ' & 1 & + & ' \\
\hline & \multirow{2}{*}{$\begin{array}{l} \\
\vdots \\
\vdots \\
0 \\
\vdots \\
2\end{array}$} & s!!!qDג!u & 1 & + & $>$ & $\sum$ & + & $>$ & + & + & + & ' & ' & + & + & ' \\
\hline & & s!.dD8,n & + & + & 1 & $>$ & + & + & + & + & + & 1 & 1 & 1 & + & I \\
\hline & \multirow{2}{*}{ 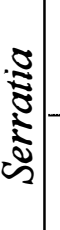 } & sua! opfanb! 1 & 1 & $>$ & $>$ & + & ' & 3 & + & + & + & $\varepsilon$ & ' & + & 1 & ' \\
\hline & & 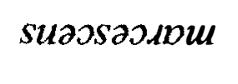 & 1 & $>$ & + & + & ' & $3^{3}$ & + & + & 8 & + & 1 & + & ' & ' \\
\hline \multirow{4}{*}{ 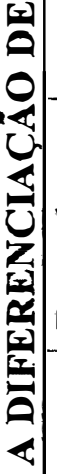 } & \multirow{4}{*}{ 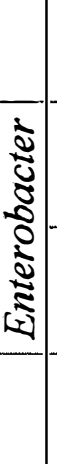 } & !anpp p!ufo $H$ & 1 & $>$ & $>$ & $>$ & ' & ; & + & + & 1 & + & $>$ & + & 1 & $>$ \\
\hline & & sauaboגan & 1 & I & + & + & 1 & 1 & + & + & $>$ & + & 1 & + & ' & $>$ \\
\hline & & วDวDO & 1 & ' & + & + & ' & $3^{3}$ & + & + & $>$ & ' & + & + & 1 & $>$ \\
\hline & & 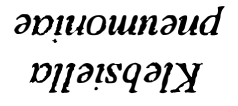 & 1 & $>$ & + & + & ' & + & + & I & 1 & + & I & 1 & 1 & + \\
\hline \multirow{5}{*}{ 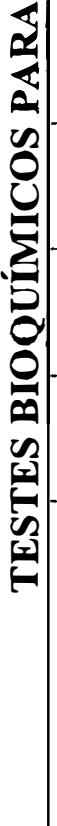 } & & $\begin{array}{c}\text { !!puna.1f } \\
\text { גapopqo.14?D }\end{array}$ & ' & + & ' & + & + & 3 & + & + & 1 & ' & $>$ & $>$ & 1 & $>$ \\
\hline & & $\begin{array}{c}\text { !ydкч1 } \\
\text { pllauоu!pS }\end{array}$ & ' & + & ' & ' & 3 & 3 & ' & + & 1 & + & 1 & 1 & ' & ' \\
\hline & & $\begin{array}{c}\text { eord!t } \\
\text { plauou|pS }\end{array}$ & ' & + & I & $>$ & + & ' & ' & + & 1 & + & 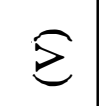 & + & ' & 1 \\
\hline & & 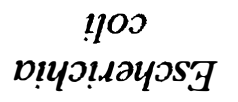 & + & + & 1 & ' & 1 & 1 & ' & $>$ & 1 & $>$ & $>$ & $>$ & 1 & 1 \\
\hline & & & 음 & 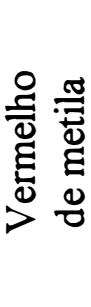 & 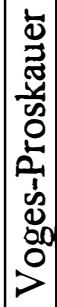 & 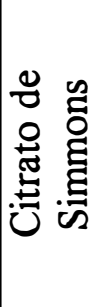 & 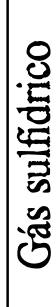 & : & $Z$ & 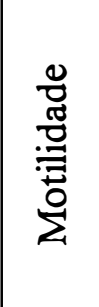 & 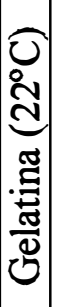 & 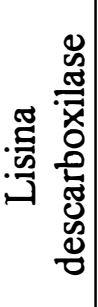 & 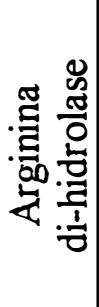 & 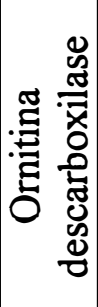 & 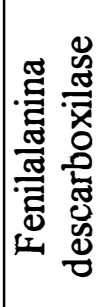 & 莺 \\
\hline
\end{tabular}




\begin{tabular}{|c|c|c|c|c|c|c|c|c|c|c|c|c|c|c|c|}
\hline & & 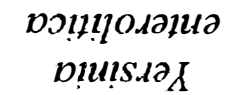 & ' & ' & + & 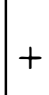 & ' & $p$ & ( & & $\geq$ & + & + & ' & ' \\
\hline 웛 & & 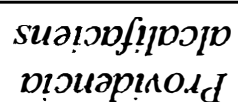 & $>$ & ' & $>$ & ' & 1 & ' & $t$ & & ' & ' & 1 & ' & ' \\
\hline : & $\S$ & s!!!qD.!!u & + & ' & $>$ & ' & ' & $p$ & ( & & ' & ' & ' & ' & , \\
\hline 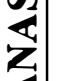 & 2 & s!.ub8/na & $>$ & ' & + & ' & 1 & $>$ & 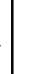 & & 1 & ' & ' & ' & ' \\
\hline 国 & $:$ & sua!̣bfanb!l & $>$ & $>$ & + & $\begin{array}{lll}+ & & -\end{array}$ & ' & + & 2 & & 8 & + & + & t & $>$ \\
\hline$\stackrel{\infty}{\infty}$ & ڤ & sиวоsวэ.ищ & $>$ & ' & + & t & ' & t+ & 12 & & $>$ & + & ' & ' & ' \\
\hline a & & !әхро р!ufo & + & $>$ & $>$ & + & ' & $>$ & . & & ' & ' & + & I & + \\
\hline 囯 & $\begin{array}{l}\bar{\Xi} \\
\bar{g}\end{array}$ & sวนว8̊одр & + & + & + & + & ' & + & t & & + & + & + & + & + \\
\hline 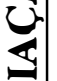 & $\underset{\mathbf{z}}{\stackrel{\Xi}{ \pm}}$ & әрэрор & + & $\Sigma$ & + & + & $>$ & 2 & 2 & & $>$ & + & + & I & + \\
\hline 帘 & & $\begin{array}{c}\text { ap!uounaud } \\
\text { pllotsqalX }\end{array}$ & + & + & + & $\begin{array}{llll}+ & & l & -\end{array}$ & $>$ & t & 2 & & + & + & + & + & + \\
\hline $\begin{array}{l}2 \\
\\
\\
\end{array}$ & & 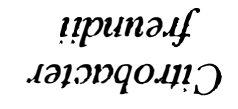 & + & $\Sigma$ & $>$ & + & $>$ & $p$ & , & & ' & + & + & $>$ & + \\
\hline ấ & & 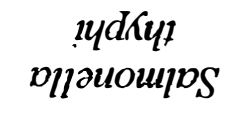 & ' & ' & 1 & + & 1 & 1 & 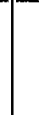 & , & ' & + & ' & 1 & ' \\
\hline$\underbrace{2}$ & & $\begin{array}{c}\text { eord!l } \\
\text { pllououाpS }\end{array}$ & + & ' & 1 & + & $\stackrel{2}{*}^{*}$ & ' & & I & $>$ & + & ${ }_{+}^{*}$ & ' & + \\
\hline 官 & & 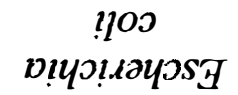 & + & + & $>$ & + & $>$ & $1>$ & & ' & ' & $>$ & + & $>$ & $>$ \\
\hline 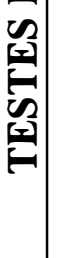 & & & 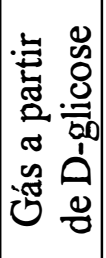 & 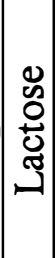 & 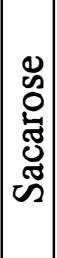 & 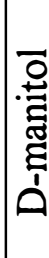 & $\begin{array}{l}\bar{O} \\
\cdot \frac{ \pm}{0} \\
\bar{\Xi} \\
\end{array}$ & 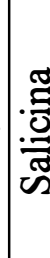 & : & & 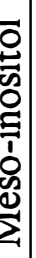 & $\begin{array}{l}0 \\
.0 \\
.0 \\
0 \\
0 \\
0 \\
0\end{array}$ & 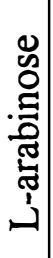 & 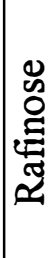 & 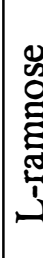 \\
\hline
\end{tabular}

